\title{
АКТИВНАЯ ТЕКТОНИКА И ПАЛЕОСЕЙСМИЧНОСТЬ ВОСТОЧНОЙ ЧАСТИ ИССЫК-КУЛЬСКОЙ КОТЛОВИНЫ (КЫРГЫЗСТАН, ТЯНЬ-ШАНЬ)
}

Корженков А. М., Деев Е. В., Турова И. В., Абдиева С. В., Иванов С. С., Лю Ц. -., Рогожин Е. А., Мажейка Й. В., Стрельников А. А., Усманова М. Т., Фортуна А. Б.

\begin{abstract}
Аннотация
Изучены внутривпадинные поднятия на востоке Иссык-Кульской котловины: Малый Оргочор, Оргочор, Бирбаш, Сухой Хребет, Ичкетосма и Тосма. Они представляют собой приразломные антиклинальные ассиметричные складки, в пределах которых в деформации вовлечены неогеновые и четвертичные отложения. Асимметрия складок выражена в наличии у них пологих и протяженных южных крыльев и более коротких и крутых - северных. Осложняющие северные крылья складок разломы являются сегментами активных в позднечетвертичное время ЮжноИссыккульского и Каркаринского разломов взбросовой кинематики. Для обоих разломов установлена левосторонняя компонента горизонтального смещения. Пространственное положение и кинематика Южно-Иссыккульского и Каркаринского разломов указывает на то, что фронт деформаций от хребта Терскей Ала-Тоо за неотектонических этап распространился практически на все осадочное выполнение востока Иссык-кульской впадины. Первичные и вторичные сейсмогенные деформации, обнаруженные вдоль Южно-Иссыккульского и Каркаринского разломов, указывают на то, что в позднем плейстоцене и голоцене они неоднократно генерировали сильные землетрясения с $\mathrm{M} \geq 7$, I $\geq$ IX баллов. Тренчинговые исследования показали, что с ЮжноИссыккульским разломом связаны исторические землетрясения, произошедшие с разницей в тысячу лет - в I и X-XI вв. н.э. Новые данные по сейсмотектонике и палеосейсмичности региона позволяют скорректировать оценку сейсмического потенциала восточной части Иссык-Кульской впадины.
\end{abstract}

\section{Ключевые слова:}

внутривпадинные поднятия, сильные палеоземлетрясения, разломные уступы, сейсмиты, ЮжноИссыккульский и Каркаринский разломы, Восточное Прииссыккулье 
УДК 551.248+ 550.34

\title{
АКТИВНАЯ ТЕКТОНИКА И ПАЛЕОСЕЙСМИЧНОСТЬ ВОСТОЧНОЙ ЧАСТИ ИССЫК-КУЛЬСКОЙ КОТЛОВИНЫ (КЫРГЫЗСТАН, ТЯНЬ-ШАНЬ)
}

\section{А.М. Корженков ${ }^{1,2}$, Е.В. Деев ${ }^{3,4,5}$, И.В. Турова ${ }^{3,4}$, С.В. Абдиева ${ }^{2}$, С.С. Иванов ${ }^{6}$, Ц. Лю ${ }^{7}$,} Й.В. Мажейка ${ }^{8}$, Е.А. Рогожин ${ }^{1}$, А.А. Стрельников ${ }^{1}$, А.Б. Фортуна ${ }^{2}$, М.Т. Усманова ${ }^{9}$

${ }^{1}$ Институт физики Земли им. О.Ю. Шмидта РАН, 123995, Москва, ул. Бол. Грузинская, 10, Россия

${ }^{2}$ Кыргызско-Российский Славянский университет им. Б.Н. Ельцина, 720000, Бишкек, ул. Киевская, 44, Кыргызстан

${ }^{3}$ Институт нефтегазовой геологии и геофизики им. А.А. Трофимука СО РАН, 630090, Новосибирск, просп. Академика Коптюга, 3, Россия

${ }^{4}$ Новосибирский государственный университет, 630090, Новосибирск, ул. Пирогова, 2, Россия

${ }^{5}$ Институт географии РАН, 119017, Москва, Старомонетный переулок, 29, Россия

${ }_{6}^{6}$ Кыргызский национальный университет им. Ж. Баласагына, факультет международных отношений и востоковедения, 720033, Бишкек, ул. Фрунзе, 547, Кыргызстан ${ }^{7}$ Institute of Geology, China Earthquake Administration, 100029, Huayanli Str., 1A, Chaoyang District, Beijing, China

${ }^{8}$ State Science Institute Nature Research Centre, Akademijos Str., 2, LT-08412, Vilnius, Lithuania ${ }^{9}$ Институт сейсмологии им. Г.А. Мавлянова АН Республики Узбекистан, 100128, Ташкент, ул. Зулфияхонум, 3, Республика Узбекистан

\begin{abstract}
АННОТАЦИЯ
Изучены внутривпадинные поднятия на востоке Иссык-Кульской котловины: Малый Оргочор, Оргочор, Бирбаш, Сухой Хребет, Ичкетосма и Тосма. Они представляют собой приразломные антиклинальные ассиметричные складки, в пределах которых в деформации вовлечены неогеновые и четвертичные отложения. Асимметрия складок выражена в наличии у них пологих и протяженных южных крыльев и более коротких и крутых - северных. Осложняющие северные крылья складок разломы являются сегментами активных в позднечетвертичное время Южно-Иссыккульского и Каркаринского разломов взбросовой кинематики. Для обоих разломов установлена левосторонняя компонента горизонтального смещения. Пространственное положение и
\end{abstract}


кинематика Южно-Иссыккульского и Каркаринского разломов указывает на то, что фронт деформаций от хребта Терскей Ала-Тоо за неотектонических этап распространился практически на все осадочное выполнение востока Иссык-кульской впадины. Первичные и вторичные сейсмогенные деформации, обнаруженные вдоль Южно-Иссыккульского и Каркаринского разломов, указывают на то, что в позднем плейстоцене и голоцене они неоднократно генерировали сильные землетрясения с M $\geq 7$, I $\geq$ IX баллов. Тренчинговые исследования показали, что с Южно-Иссыккульским разломом связаны исторические землетрясения, произошедшие с разницей в тысячу лет - в I и X-XI вв. н.э. Новые данные по сейсмотектонике и палеосейсмичности региона позволяют скорректировать оценку сейсмического потенциала восточной части Иссык-Кульской впадины.

Ключевые слова: внутривпадинные поднятия, сильные палеоземлетрясения, разломные уступы, сейсмиты, Южно-Иссыккульский и Каркаринский разломы, Восточное Прииссыккулье, Северный Тянь-Шань

\section{ВВЕДЕНИЕ}

Работа по изучению поверхностных эффектов сильных землетрясений в ИссыкКульской котловине (рис. 1) началась еще вначале XX века, когда русские ученые исследовали весной 1911 г. эпицентральную область катастрофического Кебинского (03.01.1911, $\mathrm{M}_{\mathrm{S}}=8.2, \mathrm{I}_{\mathrm{O}}=\mathrm{X}-\mathrm{XI}$ баллов) землетрясения [Богданович и др., 1914]. Во второй половине XX века киргизскими исследователями были изучены первичные и вторичные поверхностные деформации Сары-Камышского (05.06.1970 г., $\mathrm{M}_{\mathrm{lh}}=6.8$, IO $=$ VIII-IX баллов) и Жаланаш-Тюпского (24.03.1978 г., $\mathrm{M}_{\mathrm{lh}}=7.0, \mathrm{I}_{\mathrm{O}}=\mathrm{VIII-IX} \mathrm{баллов)} \mathrm{землетрясений}$ [Григоренко и др., 1973; Айталиев, 1981]. В это же время в регионе сотрудниками Института сейсмологии Киргизской ССР фиксируются морфологически выраженные палеосейсмодислокации и участки их концентрации [Утиров, 1978, 1993].

C начала XXI века на территории Кыргызстана начинают активно работать международные экспедиции. Для изучения первичных поверхностных разрывов палеоземлетрясений, в том числе и в Иссык-Кульской впадине, стал широко использоваться метод тренчинга - анализ разломных уступов в траншеях [Абдрахматов и др., 2001; Korjenkov et al., 1999, 2006b; Chediya et al., 2000; Thompson, 2001; Bowman et al., 2004b]. Стала понятна структура сейсмогенных разломов, появилась возможность достоверной параметризации палеосейсмических событий. Отобранные из стенок траншей пробы для определения абсолютного возраста деформированных слоев дали уникальную возможность в пределах ошибки радиоуглеродного и люминесцентных 
методов определить возраст, а иногда и повторяемость сильных палеоземлетрясений вдоль сегментов активных разломов на протяжении многих тысяч лет.

Авторы статьи на протяжении последних 20 лет систематически исследуют сейсмотектонику Иссык-Кульской впадины. Морфоструктурные и тренчинговые исследования, дополненные археосейсмологическими изысканиями и анализом вторичных сейсмогенных деформаций - сейсмитов, позволили определить сейсмотектоническую позицию эпицентральных зон и возраст ряда позднеплейстоцен-голоценовых и исторических землетрясений в северном [Корженков, 2006; Корженков и др., 2016а; Деев, Корженков, 2016; Korjenkov et al., 2006а], западном [Поволоцкая и др., 2006; Корженков и др., 2000, 2001, 2007; 2016в; Deev et al., 2018] и южном [Корженков и др., 2014, 2016б; Деев и др., 2016; Gladkov et al., 2016; Korzhenkov, Deev, 2017] Прииссыккулье. Накопленные данные дали возможность по-новому взглянуть на структуры земной коры Северного Тянь-Шаня, которые отвественны за возникновение сильных землетрясений. Стала более понятной история формирование зон сочленения горных хребтов - Кунгей Ала-Тоо и Терский Ала-Тоо - с Иссык-Кульской впадиной. Здесь более полно были изучены, прежде всего, краевые разломы, разделяющие палеозойские породы хребтов от кайнозойских отложений впадины. Установлено, что помимо краевых разломов, активными сейсмогенерирующими структурами являются разломы, ограничивающие адырные (форберговые) поднятия, которые отделяют от основной части Иссык-Кульской впадины рамповые и полурамповые бассейны. Особенно такая ситуация оказалась особенно характерной для южной части впадины [Корженков и др., 2014, 2019; Деев и др., 2016; Деев, 2018; Korzhenkov, Deev, 2017].

Таким образом, наименее изученной в плане сейсмотектоники остается восточная часть Иссык-Кульской котловины. Ранее обнаруженные деформации археологических объектов и сейсмиты в верхнечетвертичных отложениях [Корженков и др., 2015, 2018а; Korjenkov, 2000; Bowman et al., 2004a] свидетельствуют в пользу необходимости исследований черт активной тектоники и сейсмотектоники этой части котловины. Ключевыми объектами здесь являются внутривпадинные поднятия. Целью представляемой статьи является анализ структуры этих поднятий, их связи с активными разломами и вклад в сейсмичность региона.

\section{МЕТОДИКА ИССЛЕДОВАНИЙ}

Разломные уступы, нарушающие различные элементы аккумулятивного и эрозионного рельефа, были предварительно намечены с использованием высокоразрешающих космоснимков QuickBird, доступных в пакете GoogleEarth. Полевое 
картирование разломных уступов включало детализацию их морфологии (высота, протяженность, сегментация) с использованием портативных GPS. Смещения тальвегов водотоков, апексов конусов выноса, наличие запирающих хребтов позволили установить и измерить амплитуды сдвиговых перемещений вдоль разломных уступов.

Для детализации черт рельефа на северном склоне горы Бирбаш проведена панорамная фотосъемка с использованием квадрокоптера. Здесь же выполнено тренчинговое исследование одного из разломных уступов. При этом выполнено послойное описание восточной стенки траншеи с фиксацией фациальных характеристик отложений, взаимоотношений слоев, выявлением сейсмогенного разрыва, определением типа и амплитуды смещения по нему, коллювиальных клиньев, отбором проб на ${ }^{14} \mathrm{C}$ определение абсолютного возраста отложений.

Определение ${ }^{14} \mathrm{C}$ возрастов 1 образца палеопочвы и 2 образцов гумусированной супеси выполнено в Радиоизотопной лаборатории Государственного научноисследовательского института «Центр природных исследований» (Вильнюс, Литва). Калиброванные возраста рассчитаны с использованием программы OxCal 4.3 [Bronk Ramsey, 2001; Bronk Ramsey et al., 2010] и калибровочной кривой IntCal2013 [Reimer et al., 2013].

При характеристики геологического строения территории использованы геологические карты масштаба 1:200 000 [Чабдаров и др., 1961; Шендерович, Макаров, 1965; Турчинский, 1970]. В пределах естественных обнажений исследованы неогенчетвертичные отложения, слагающие внутривпадинные поднятия. В обнажениях фиксировались слои и их взаимоотношения с учетом их цветовых характеристик, гранулометрии и окатанности обломочного материала. Задокументированы различные деформации, нарушающие элементы первичной седиментационной слоистости. Определялись элементы залегания слоев и плоскостных деформаций.

Оценка магнитуд и интенсивности палеоземлетрясений проводилась на основе эмпирических зависимостей между ними и параметрами сейсмогенных разрывов (Nikonov 1988; Wells, Coppersmith, 1994). Типы сейсмитов и гранулометрия вовлеченных в сейсмическое разжижение осадков позволила с учетом данных из [Rodríguez-Pascua et al., 2000; Bezerra et al., 2005; Papathanassiou et al., 2005; Deev et al., 2019] оценить параметры землетрясений, при которых сформировались эти вторичные деформации.

\section{РЕЗУЛЬТАТЫ ИССЛЕДОВАНИЙ}

Краткий обзор неотектоники района исследований. Иссык-Кульская впадина одна из крупнейших внутригорных впадин Северного Тянь-Шаня (рис. 1). Ее длина 
достигает 250 км, ширина - 80 км. В пределах котловины расположено озеро Иссык-Куль с максимальной глубиной 668 м. Впадина выполнена кайнозойскими отложениями мощностью почти 5000 м [Чедия, 1986; Фортуна, 1993]. С юга она ограничена хребтом Терскей-Ала-Тоо, максимальная высота которого составляет 5281 м, с севера - хребтом Кунгей-Ала-Тоо с высотами до 4760 м. С учетом высот горных хребтов, мощностей кайнозойских отложений в центральной части Иссык-Кульской впадины и глубины ИссыкКуля амплитуда вертикальных кайнозойских движений в Прииссыккулье составила около 10 км [Чедия, 1986; Deev et al., 2018].

Сочленение Кунгейского хребта и Иссык-Кульской впадины происходит по эшелонировано надстраивающим друг друга Тогуз-Булакскому, Культорскому, Аксуйскому и Талды-Булакскому краевым разломам (рис. 1). Согласно [Selander et al., 2012] эта зона имеет более сложное строение и может быть описана как “flower structure”. Модель предполагает, что косо ориентированные к основному субмеридиональному направлению сжатия Чилико-Кеминские разломы левосдвиговой кинематики генерируют систему крутых на глубине и выполаживающихся к дневной поверхности листрических взбросонадвигов и взбросо-сдвигов. Развитие каждого нового разлома к югу от предыдущего обеспечивает рост Кунгейского хребта и последовательное вовлечение новых участков предгорного аллювиально-пролювиального шлейфа Иссык-Кульской впадины в поднятие. Деформации вдоль активных разломов сопровождаются формированием локальных антиклиналей и синклиналей, разломных уступов, вдоль которых фиксируются вертикальные и горизонтальные смещения плейстоцен-голоценовых аккумулятивных и эрозионных форм рельефа [Корженков, 2000; Корженков и др., 2011; Bowman et al., 2004b; Selander et al., 2012; Deev et al., 2018]. Скорости позднечетвертичных сдвиговых смещений по разломам составляют до 1.5 мм/год, вертикальных - до 0.37 мм/год [Selander et al., 2012]. Формирование большинства разломных уступов в этой зоне связано с сейсмогенными подвижками при сильных древних и исторических землетрясениях [Джанузаков и др., 2003; Корженков и др., 2011, 2016б, 2018а,б; Деев, Корженков, 2016). С зоной Южного Чилико-Кеминского разлома связана сильнейшая сейсмогенная катастрофа - Кеминское (Кебинское) землетрясение (03.01.1911, $\mathrm{M}_{\mathrm{s}}=8.2, \mathrm{I}_{\mathrm{o}}=10-11$ ) [Богданович и др., 1914].

Подобно северу строятся взаимоотношения Иссык-Кульской впадины и хребта Терскей Ала-Тоо (рис. 1). Левосдвиговые движения вдоль Центрально-Терскейского разлома обеспечивают формирование цветочной структуры хребта. В результате он активно надвигается на впадину по Предтерскейскому разлому. В тоже время, в пределах вовлекаемой в деформации предгорной равнины, формируется ряд передовых хребтов - 
адыров (форбергов). Возникновение этих хребтов обусловлено противоположными движениями по падающим на север взбросам, с которыми связаны эпицентральные зоны позднеплейстоцен-голоценовых и исторических землетрясений. В результате между хребтом и адырами формируются небольшие по размерам рамповые и полурамповые впадины [Чедия, 1986, Корженков, 1987, 2006, 2018а, 2019; Деев и др., 2016; Деев, 2018; Korjenkov et al., 2006b; Macaulay et al., 2014; Korzhenkov, Deev, 2017].

Еще одной важной в плане сейсмотектоники и активной тектоники Иссык-Кульской впадины группой структур являются ее внутренние поднятия. К примеру, к западу от озера хорошо известна антиклиналь Боз-Бармак (рис. 1). В ее пределах в поднятия вовлечены отложения миоцен-плиоценовой иссык-кульской свиты $\left(\mathrm{N}_{1-2} i s\right)$ и четвертичные образования. Рост этой антиклинальной структуры явился причиной разрыва стока р. Чу в озеро Иссык-Куль. На западной ее периклинали выявлен разломный уступ, который мог быть источником сейсмических колебаний с интенсивностью не менее 8 баллов по шкале MSK-64, которые привели к деформациям стен городищ Сары-Булун в XII в. В озерных отложениях антиклинали Боз-Бармак зафиксированы горизонты сейсмитов, соответствующие 7 землетрясениям с $\mathrm{M} \geq 5-5.5$, произошедшим около 22 тыс. лет назад [Корженков и др., 2016в; Deev et al., 2018].

Именно поэтому нас заинтересовали изолированные внутривпадинные поднятия явные свидетельства активной тектоники на востоке Иссык-Кульской котловины. Судя по геологическим картам, в их пределах деформированными оказываются верхнечетвертичные отложения [Чабдаров и др., 1961; Шендерович, Макаров, 1965; Турчинский, 1970].

Оргочорская и Малая Оргочорская антиклинали. К востоку от залива Покровский оз. Иссык-Куль расположена s-образная в плане система поднятий (рис. 2 a). Она выделяется на фоне слегка наклонной от адырных поднятий хребта Терскей Ала-Тоо в сторону озера аллювиально-пролювиальной равнины, сложенной верхнечетвертичными отложениями. Наиболее приподнятая восточная часть системы поднятий - гора Оргочер имеет размеры в поперечнике $15 \times 7$ км, абсолютную высоту 2061.9 м и плавно изменяет свою плановую конфигурацию с северо-западной на северо-восточную. Гора Малый Оргочер (1751 м) находится западнее. Она ориентирована своей длиной осью на северовосток и имеет поперечные размеры $3 \times 1$ км. В геологическом плане оба поднятия представляют собой ассиметричные антиклинали, имеющие более длинные пологие южные крылья и короткие крутые, осложненные разломами, северные крылья (рис. 2 б, в). В поднятие вовлечены терригенные отложения миоцен-плиоценовой иссык-кульской свиты, а также средне-верхнеплейстоценовые образования [Шендерович, Макаров, 1965; 
Турчинский, 1970]. Стык между Малой Оргочерской и Оргочерской антиклиналями прорезается р. Чон-Кызылсуу. Наконец, в качестве западного продолжения оргочорских поднятий можно рассматривать вдающийся в Иссык-Куль мыс Кара-Булун (рис. 2 а).

С целью анализа активной тектоники и сейсмотектоники мы обследовали северные крылья антиклиналей. При приближении к селу Боз-Бешик на западном склоне горы Оргочор появляются небольшие эрозионные промоины (рис. 3 а), в которых отчетливо видны падающие на северо-восток (аз. $310^{\circ}$ ) под углом $25^{\circ}$ неогеновые отложения иссыккульской свиты: параллельно-переслаивающиеся плитчатые глины, супеси, средне- и мелкозернистые пески с примесью мелкой гальки. Перечисленные отложения слагают здесь северное - короткое и крутое крыло Оргочорской антиклинали.

На северном крыле Оргочорской антиклинали отмечаются деформации не только неогеновых отложений. Здесь по разлому вздернуты низкие, включая первую надпойменную, террасы реки Чон-Кызылсуу. Так первая надпойменная терраса в месте пересечения разломом одной из проток реки Чон-Кызылсуу разорвана двумя разломными уступами, которые вертикально смещают поверхность террасы на 1 и 2 м (рис. 3 б). Эти разломные уступы являются поверхностными разрывами сильных палеоземлетрясений. Вполне возможно предположить, что нижний уступ возник в результате одной сейсмогенной подвижки. Соответственно магнитуда этого палеособытия, с использованием корреляционных зависимостей из [Nikonov, 1988], может быть оценена как $\mathrm{M}=7.1 \pm 0.5$.

Следы палеоземлетрясений на западном окончании Оргочорской антиклинали не ограничиваются наличием разломных уступов. На северо-западной окраине села БозБешик в придорожном карьере видны сейсмогенные конволюции - сейсмиты, нарушающие седиментационную текстуру верхнеплейстоценовых (?) отложений. Сейсмическое разжижение привело к наклону и значительному перемешиванию озерных глин и аллювиальных галечников (рис. Зв). Вовлечение в сейсмическое разжижение отложений галечной размерности характерно для землетрясений с $\mathrm{M} \geq 7$-8 [RodríguezPascua et al., 2000; Bezerra et al., 2005; Deev et al., 2019]. Отметим, что сейсмиты в позднеплейстоценовых отложениях широко распространены на территории ИссыкКульской впадины [Korjenkov, 2000; Bowman et al., 2004a; Поволоцкая и др., 2006; Gladkov et al., 2016; Deev et al., 2018].

Антиклиналь Бирбаш. В 15 к северо-востоку от восточной окраины Оргочерской антиклинали, на южном берегу залива Пржевальского, находится еще одно субширотно вытянутое поднятие размерами $8 \times 3$ км - гора Бирбаш (абсолютная высота 1811.8 м) (рис. 4). По своей геологической структуре это поднятие аналогично вышеописанным 
складкам. На крыльях и в ядре антиклинали обнажаются отложения верхней части иссыккульской свиты [Шендерович, Макаров, 1965]. На крыльях они перекрываются средневерхнеплейстоценовыми пролювиальными образованиями, которые, в свою очередь погружаются под широкую наклонную аллювиально-пролювиально-озерную равнину позднеплейстоценового возраста. Таким образом, морфологическое выражение в рельефе антиклиналь Бирбаш получила лишь в позднечетвертичное время. Южное крыло антиклинали пологое и длинное, северное крыло - более крутое и короткое. Его формирование осложнено активным разломом взбросовой кинематики [Шендерович, Макаров, 1965; Бачманов и др., 2017].

Наши палеосейсмологические исследования позволили выявить признаки активности этого разлома. Весь северный склон горы Бирбаш нарушен разломными уступами и представляет собой лестницу со ступенями различной сохранности (рис. 5 а). Некоторые из уступов маскируются зарослями колючего кустарника (рис. 5 б). Видно, что на склоне могут присутствовать сегменты сближенных уступов (рис. 5 в).

Внутренняя структура одного из таких сегментов (рис. 5 а, 6 а) была изучена нами в траншее. Задокументирована восточная стенка траншеи (рис. 6 б). В основании разреза залегает слой 1 , представленный лессовидными суглинками видимой мощностью более 0.7 м. Целостность слоя нарушена взбросом F1, который падает на юг под углом 65-70 Амплитуда смещения кровли слоя 1 вдоль линии падения разлома - 0.5 м. Деформации срезаются и запечатываются слоем 2 - делювиальные пески с плавающей галькой и гравием. Наибольшую мощность слой 2 имеет непосредственно к северу от разломной плоскости F1 - 0.6 м. В слои 1 и 2 вложена линза слоя 3 мощностью 0.2 м. Она сложена песком с гравием и дресвой и представляет собой заполненное отложениями русло ирригационного канала (арыка I). Судя по ${ }^{14} \mathrm{C}$ возрасту образца палеопочвы (BRB-1), фрагмент которой присутствовал в основании слоя 2, - $1936 \pm 39$ лет (FTMC-25-4), калиброванный возраст - 20-90 гг. н.э. (табл. 1), - этот арык был прорыт усунями, потомками европеоидных саков (скифов), у которых было разделение на скотоводов и земледельцев. Слои 4-6 представляют собой эоловые отложения мощностью до 0.5 м, представленные лессовидными суглинками (слои 4 и 6) и песком (слой 5). В лессовидные суглинки слоя 4 вложена линза - слой 7 мощностью до 0.5 м. Она сложена супесью, местами гумусированной, насыщенной в базальной части гравийно-дресвяным материалом, и представляет собой заполненное отложениями русло ирригационного канала (арыка II). Слой 8 частично срезает или перекрывает подстилающие образования. Он сложен делювиальным разнозернистым песком, насыщенным дресвяно-гравийным материалом. Также присутствует мелкий щебень. В этот матрикс погружены 
разнообразные по форме отторженцы лессовидных суглинков, которые представляют собой фрагменты подстилающих отложений. Размер наиболее крупного из таких отторженцев достигает в поперечнике 2.4 м. В отложения слоя 8 вложена линза (слой 9) мощностью до 0.7 м, сложенная супесью, местами гумусированной, насыщенной в базальной части гравийно-дресвяным материалом. По нашему мнению, она представляет собой заполненное отложениями русло очередного ирригационного канала (арыка III). Разрез траншеи венчается современной почвой (слой 10) мощностью до 0.6 м.

Описанный разрез имеет следующую палеосейсмологическую интерпретацию. В нем присутствуют следы двух палеоземлетрясений. Первому из них соответствует взброс F1 и коллювиальный клин - слой 2, образовавшийся при эрозии висячего крыла разлома. Смещение в 0.5 м по линии падения разлома позволяет с использованием корреляционных зависимостей из [Wells, Coppersmith, 1994] оценить минимальную моментную магнитуду палеосейсмического события как $\mathrm{Mw}=6.5-6.7$. Судя по возрасту образца палеопочвы из основания коллювиального клина, землетрясение произошло в I в. н.э.

Формирование эоловых отложений слоев 4-6 соответствует времени стабилизации разломного уступа. В качестве коллювиального клина очередной сейсмической подвижки, обновившей уступ, следует рассматривать отложения слоя 8. Сам сейсмогенный разрыв, видимо, находится несколько южнее и траншеей не вскрыт. Тем не менее, результат средневековой сейсмической подвижки хорошо выражен в рельефе. Образовавшийся во время второго землетрясения разломный уступ имеет высоту 1 м (рис. 6 а, в). Однако, кроме вертикальной, имеется еще и 2-х метровая левосторонняя горизонтальная составляющая движений. Ее удалось определить по смещению русла временного водотока (рис. 6 в). Параметры разломного уступа, с использованием корреляционных зависимостей из [Nikonov, 1988; Wells, Coppersmith, 1994], позволяют оценить минимальную величину магнитуды землетрясения - $\mathrm{M}=6.9-7.2$.

О возрасте второго землетрясения позволяют судить результаты радиоуглеродного датирования базальной части отложений, заполняющих арык III. По нашему мнению, после второго землетрясения и прекращения функционирования арыка II, сразу же был отрыт новый - арык III. ${ }^{14} \mathrm{C}$ возраст отобранного здесь образца гумусированной супеси

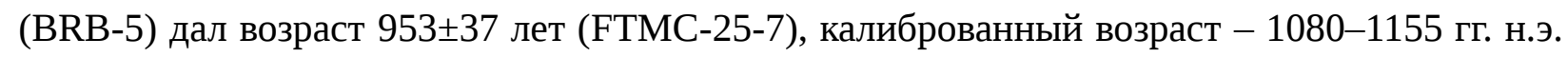
(табл. 1). Полученный возраст является минимальный для второго сейсмического события.

На северном склоне горы Бирбаш, кроме первичных поверхностных разрывов палеоземлетрясений (разломных уступов) нами были обнаружены также сейсмогенные конволюции в озерных осадках - сейсмиты (рис. 7 а). Они возникли в результате эффекта разжижения при палеоземлетрясении в рыхлых водонасыщенных отложениях, 
представленными серыми субгоризонтально-параллельнослоистыми крупнозернистыми песками и светло-коричневыми глинами. Мощность пачки слоев, вовлеченных в деформацию, 75 см. Она находится в разрезе между аналогичными по составу недеформированными слоями. Морфологически сейсмиты представлены складками, конволютной слоистостью (рис. 7 б), пламеневидными структурами и структурами нагрузки (рис. 7 в), псевдонодулями, представляющими собой отторженцы глин, погруженные в песок.

В отсутствии определений абсолютного возраста для отложений, вмещающих сейсмиты, их возраст приблизительно можно оценить по возрасту самой озерной николаевской террасы, в строении которой участвуют пески и глины. Отложения, слагающие террасу, которая прослеживается вокруг всего озера Иссык-Куль на абсолютной высоте 1640 м, были датированы радиоуглеродным методом - 31.3-29.4 калиброванных тысяч лет [Алешинская и др., 1971], т.е. изученные сейсмиты имеют позднеплейстоценовый возраст. Магнитуды сейсмических событий, при которых возникали вторичные деформации составляли не менее 5.0-5.5 [Papathanassiou et al., 2005].

К западу от Бирбашской антиклинали протягивается субширотный уступ длиной в несколько километров и высотой до 25 м (рис. 4, 8 а), который ошибочно может быть принят за частично размытый озерных клиф. Однако это не так. Своим оформлением в рельефе уступ обязан сейсмическим подвижкам по активному разлому. Вторичные сейсмогенные деформации в отложениях, формирующих уступ, можно наблюдать в придорожном обнажении, которое находится в 550 м к юго-западу от устья р. Ирдык, впадающей в оз. Иссык-Куль. В нем вскрываются дельтовые серые гравийно-галечники, крупнозернистые пески и палевые глины (рис. 8 б, в). Здесь видны малоамплитудные внутрислоевые взбросо-надвиги (с амплитудами смещений 20-40 см) и отторженцы озерных глин, погрузившиеся в галечники. Эти деформации свидетельствуют об сейсмогенном разжижении описываемых отложений при землетрясении с магнитудой не менее 7. Учитывая высоту висячего крыла уступа - около 1640 м над у.м., то есть уровень упоминавшейся уже ранее николаевской озерной террасы, возраст отложений, слагающих разломный уступ, должен быть тот же - конец позднего плейстоцена. В непосредственной близости (рис. 4) расположены ранее выявленные Ирдыкский и Пристаньский разрезы с позднеплейстоценовый сейсмитами [Bowman et al., 2004a].

Антиклинали Сухой Хребет, Ичкетосма и Тосма. Основными притоками, приносящими максимальное количество воды в озеро Иссык-Куль являются реки Тюп и Джергалан. Они текут в восточной части котловины, не соединяясь, десятки километров 
на запад параллельно друг другу. Долины рек разделены широтно вытянутым поднятием, которое имеет протяженность около 70 км и с запада на восток включает в себя: урочище Сухой Хребет (максимальная отметка - г. Сарыдюбе -1728.5 м), глубоко вдающийся в воды Иссык-Куля, горы Ичкетосма (1893.3 м) и Тосма (2378.3 м). С точки зрения геологического строения все эти горы представляют собой ассиметричные антиклинали с южным более длинным и пологим крылом и северным крутым коротким приразломным крылом. В поднятие вовлекаются четвертичные отложения, а в привершинной части и на северных склонах гор Тосма - неогеновые отложения иссык-кульской свиты [Чабдаров и др., 1961; Шендерович, Макаров, 1965].

Разломы, осложняющие северные крылья антиклинальных складок хорошо идентифицируются в рельефе по наличию разломных уступов. Один из таких субширотных линейных уступов высотой до 15 м прослеживается по северному подножью Сухого Хребта (рис. 9 а). Он возвышается над равниной, сложенной верхнеплейстоценголоценовыми озерными осадками (рис. 9 б). На восточной окраине пос. Песчаный, в стенке карьера, вскрывающего уступ (рис. 9 б), видно субвертикальное падение средневерхнеплейстоценовых озерных глин (рис. 9 в). Южнее основного уступа в рельефе выражен еще один разломный уступ, с которым связано формирование ассиметричной антиклинальной складки следующего порядка, которая нарушает сравнительно плоскую поверхность Сухого Хребта и имеет туже асимметрию, что и основная антиклиналь (рис. 9 а, г). Помимо вертикальной составляющей смещений вдоль этого разломного уступа нами зафиксирована и сдвиговая компонента. Она идентифицируется по левостороннему смещению русла временного водотока по отношению к апексу его пролювиального конуса выноса и достигает 16 м (рис. 9 д).

Хорошо выражен в рельефе разломный уступ и у северного подножья гор Тосма (рис. 10 а). В придорожном обнажении, вскрывающем уступ в 2.7 км к востоку от села Токтоян, видно надвигание глин иссык-кульской свиты на средне-верхплейстоценовые (?) аллювиальные галечники реки Тюп (рис. 10 б). В галечниках видны неокатанные фрагменты неогеновых глин до 1.8 м в поперечнике (рис. 10 в), которые являются фрагментами разрушения под действием сил гравитации висячего крыла надвига. С учетом перекрытия описанных слоев склоновыми делювиально-коллювиальными верхнеплейстоцен-голоценовыми образованиями можно констатировать, что надвиговые подвижки по разлому носят долговременный характер.

Как и в случае с Сухим хребтом, на различных участках северного склона гор Тосма морфологически выражены серии разломных уступов. К примеру, на рис. 10 г можно видеть три самостоятельных уступа. Наиболее молодой разломный уступ высотой 1 м 
хорошо фиксируется по вертикальному смещению тальвега долины временного водотока. Если предположить, что уступ возник в результате одной сейсмогенной подвижки, то магнитуда соответствующего землетрясения, с использованием корреляционных зависимостей из [Nikonov, 1988], могла достигать $\mathrm{M}=7.1 \pm 0.5$. Для среднего и верхнего уступа по смещению элементов долины временного водотока и наличию загораживающего (барьерного) хребтика отчетливо фиксируется левосдвиговая составляющая с амплитудами 2.5 и 14 м соответственно. Помимо разломных уступов на северном склоне гор Тосма присутствуют и оползни, пространственно связанные с выходом на поверхность активного разлома. Так в 1 км на юго-запад от села Сары-Тологой в рельефе читается многофазный оползень (рис. 10 а, д). Свежая его фаза имеет обычный для оползня холмисто-западинный рельеф. Более древнее оползневое тело существенно эродировано и террасировано аллювиальными процессами в позднем плейстоцене.

\section{ОБСУЖДЕНИЕ ПОЛУЧЕННЫХ РЕЗУЛЬТАТОВ}

Мы описали выше строение внутривпадинных структур. Это надразломные антиклинальные асимметричные складки: Малая Оргочорская, Оргочорская, Бирбашская, Сухой Хребет, Ичкетосма и Тосма, сформированные вследствие взбросовых подвижек по разломам. Эти взбросы обрывают крутые и короткие северные крылья складок и падают на юг. Южные крылья складок длинные, полого погружающиеся под наклонную равнину Восточного Приссыккулья, имеющую аллювиально-пролювиальный и озерный генезис. Какова сейсмотектоническая позиция охарактеризованных структур?

Краевой Предтерскейкий разлом взбросово-надвиговой кинематики с падением разломной плоскости на юг находится на южной границе кайнозойских отложений ИссыкКульской впадины, в месте их контакта с палеозойскими породами хребта Терскей АлаТоо (см. рис. 1). Севернее, перед фронтом хребта, располагается система предгорных (адырных, форберговых) поднятий. Северная граница поднятий с наклонной аллювиально-пролювиальной равниной, спускающейся к озеру, является "гвоздиком" так называемых стратиграфических и морфологических "ножниц" (рис. 11 а, б). Здесь среднечетвертичные отложения адыров "погружаются" под верхнечетвертичные накопления наклонной равнины [Чедия и др., 1988].

Активные разломы ограничивают адырные поднятия с юга. Так, например, крутое и короткое южное крыло Джетыогузского поднятия ограничено с юга одноименным взбросом, плоскость которого падет на север (рис. 11 а, 12 а). В это же время на его северном длинном и пологом крыле видно сначала конформное налегания юрских отложений на доороегенный пенеплен, а затем (при продвижении на север) их согласное перекрытие палеоген-неогеновыми и четвертичными образованиями. Таким образом, 
возраст кайнозойских отложений к северу омолаживается, в этом же направлении более пологим становится и угол их наклона. К югу от Джетыогузского разлома, падающего к северу, проходит плоскость Предтерскейского краевого разлома, наклоненная на юг (рис. 11 а, 12 а), в результате чего между этими дизъюнктивами образовалась небольшая внутригорная впадина рампового типа, выполненная четвертичными отложениями - так называемая "Долина цветов". Подобная ситуация характерна и для других районов южного Прииссыккулья [Чедия, 1986; Корженков и др., 2014, 2018a, 2019; Деев и др., 2016; Korzhenkov, Deev, 2017]. Получается, что эти антиклинальные структуры адырных поднятий надвигаются не на впадину, а в сторону главного хребта, что, вообще говоря, против сил гравитации.

Для объяснения этого феномена в работах [Burgette, 2008; Macaulay et al., 2014] была рассмотрена модель структуры южной части Иссык-Кульской впадины, согласно которой левосдвиговые движения вдоль Центрально-Терскейского разлома генерируют “цветочную структуру” хребета Терскей Ала-Тоо (рис. 12 б). Исходя из этой модели, R.J. Burgette [2008] объяснил парадокс развития адырных поднятий существованием помимо Предтерскейского разлома еще одного разлома взбросов-надвиговой кинематики с южным падением разломной плоскости, проходящего вдоль южного побережья озера Иссык-Куль (этот разлом был ошибочно назван R.J. Burgette Предтерскейским). Мы предлагаем для этого разлома придерживаться названия Южно-Иссыккульский [Korzhenkov, Deev, 2017] (рис. 1, 12 б). Оперяющие к Южно-Иссыккульскому разлому взбросы с северным падением, по мнению R.J. Burgette [2008], отвечают за формирование адыров и возникновение между ними и надвигающимся к северу по Предтерскейскому разлому хребтом Терскейскей Ала-Тоо мелких рамповых и полурамповых впадин. Наконец, с этими адырными разломами второго порядка в Южном Прииссыккулье связаны очаговые области землетрясений с возрастом 7.3-8.4 тыс. лет (Mw = 6.5-6.9), 4.32.7 тыс. лет (Mw $\geq 7.0)$, произошедших в XI-XII вв. н.э. (Mw = 6.9-7.3), в XV-XVI вв. н.э. $(\mathrm{Mw}=6.6-7.2)$, в XVIII в. н.э. (Mw $\geq 7.0)$ [Корженков и др., 2014, 2016б, 2019; Деев и др., 2016; Деев, 2019; Korzhenkov, Deev, 2017].

В модели R.J. Burgette [2008], Южно-Иссыккульский разлом после выхода со дна Иссык-Куля на сушу в восточном направлении повторяет северный контур неогеновых отложений - адыров хребта Терскей Ала-Тоо. Однако, как было показано выше дизъюнктивная граница с северного края адыров отсутствует. С учетом вновь полученных структурно-геоморфологических данных мы предлагает в качестве восточного продолжения Южно-Иссыккульского разлома рассматривать активные разломы на северных крыльях внутривпадинных антиклинальных структур: Малый Оргочер, Оргочер, 
Бирбаш и, частично, Тосма. Палеосейсмологические исследования на северном крыле антиклинали Бирбаш показали, что кроме взбросовой компоненты движения для ЮжноИссыккульского разлома характерны современные левосдвиговые смещения.

В районе антиклинали Тосма Южно-Иссыккульский разлом сочленяется с субширотным активным разломом, который к западу протягивается до северного склона поднятия Сухой Хребет и уходит под воды Иссык-Куля (рис. 1). Кинематически этот разлом представляет собой взброс, плоскость которого также имеет южное падение. Рассматриваемый разлом является западным сегментом Каркаринского разлома, который на территории юго-восточной части Казахстана примыкает к Предтерскейскому разлому [Бачманов и др., 2017; Mackenzie et al., 2018]. В пределах Казахстана восточная часть разлома является активной структурой в позднечетвертичное время. Смещения надпойменных террас позволили оценить скорость смещения вдоль линии падения наклонной на юг плоскости разлома в $3.5^{+1.7}-0.4$ мм/год [Mackenzie et al., 2018]. В пределах северных склонов гор Тосма и Сухого хребта нами установлено, что для Каркаринского разлома кроме вертикальной имеется еще и горизонтальная компонента позднечетвертичных перемещений - левый сдвиг.

Из приведенной на рис. 1 конфигурации Южно-Иссыккульского и Каркаринского разломов и установленных их кинематических характеристик следует еще один важный вывод о неотектонической эволюции Иссык-Кульской впадины. На основе термохронологических данных ранее было установлено, что в режиме общего горизонтального субмеридионального сжатия рост хребта Терскей Ала-Тоо начался намного раньше (поздний олигоцен, около 25 млн лет назад) по сравнению с хребтом Кунгей Ала-Тоо (ранний плиоцен, около 5 млн лет назад) [Macaulay et al., 2014]. Видимо, это послужило причиной того, что фронт “южных” взбросовых деформаций в восточной части впадины достиг северного побережья Иссык-Куля, т.е. взбросы с южным падением плоскостей практически распространились здесь на весь бассейн седиментации.

Необходимо еще раз отметить совершенно отчетливые признаки сильной позднечетвертичной и современной сейсмической активности на северных крыльях исследованных внутривпадинных поднятий. Вдоль сегментов Южно-Иссыккульского и Каракаринского разломов нами выявлены разломные уступы - поверхностные разрывы сильных палеоземлетрясений с $\mathrm{M} \geq 7$. Процессы сейсмического разжижения с вовлечением аллювиальных галечников также характерны для землетрясений с такими магнитудами. Полученные датировки при тренчинговых исследованиях разломного уступа на северном крыле антиклинали Бирбаш, говорят о том, что сильные исторические землетрясения, связанные с Южно-Иссыккульским разломом, произошли около I и X-XI 
вв. н.э. Таким образом, этот разлом может генерировать сильные землетрясения с $\mathrm{M} \geq 7$, минимум, раз в тысячу лет.

В настоящее время, на «Карте сейсмического районирования территории Кыргызской Республики» [Абдрахматов и др., 2012] внутривпадинная часть Восточного Прииссыккулья относится к VIII-балльной зоне. Обнаруженные нами первичные и вторичные сейсмогенные деформации возникали при землетрясениях с магнитудой $\mathrm{M} \geq 7$ и интенсивностью I $\geq$ IX баллов. Вновь полученные данные позволяют уточнить оценку сейсмического потенциала этой части Иссык-Кульской впадины.

\section{ЗАКЛЮЧЕНИЕ}

Нами были изучены внутривпадинные поднятия на востоке Иссык-Кульской котловины. Анализ их структуры и сейсмотектонического положения позволил нам прийти к нижеследующим выводам.

1) Поднятия представляют собой приразломные антиклинальные ассиметричные складки, в пределах которых в деформации вовлечены неогеновые и четвертичные отложения. Асимметрия складок выражена в наличии у них пологих и протяженных южных крыльев и более коротких и крутых - северных.

2) Осложняющие северные крылья складок разломы являются сегментами ЮжноИссыккульского и Каркаринского разломов взбросовой кинематики, активных в позднечетвертичное время. Помимо вертикальной компоненты движений для обоих разломов установлена левосторонняя компонента горизонтального смещения.

3) Пространственное положение и кинематика Южно-Иссыккульского и Каркаринского разломов указывает на то, что фронт деформаций от хребта Терскей АлаТоо распространился с олигоцена по голоцен практически на все осадочной выполнение восточной части Иссык-кульской впадины.

4) Многочисленные разломные уступы и сейсмиты, обнаруженные вдоль сегментов Южно-Иссыккульского и Каркаринского разломов, указывают на то, что в позднем плейстоцене и голоцене здесь неоднократно происходили сейсмические подвижки с $\mathrm{M} \geq 7$, $\mathrm{I} \geq \mathrm{IX}$ баллов. Землетрясения с такими параметрами, связанные с Южно-Иссыккульским разломом, произошли около I и X-XI вв. н.э., т.е. они повторились через тысячу лет. Новые данные по сейсмотектонике и палеосейсмичности региона позволяют скорректировать оценку сейсмического потенциала восточной части Иссык-Кульской впадины.

Исследование выполнено при финансовой поддержке РФФИ в рамках научных проектов 19-55-53017 ГФЕН a, 18-55-41005 Узб m; Международного научнотехнического центра (грант № G-2153), средств государственной программ научных 
исследований Института физики Земли им. О.Ю.Шмидта РАН и Института нефтегазовой геологии и геофизики им. А.А. Трофимука СО РАН. Благодарим Д. Лужанского за помощь при проведении полевых работ. 


\section{ЛИТЕРАТУРА}

Абдрахматов К.Е., Джанузаков К.Д., Фролова А.Г., Погребной В.Н. Карта сейсмического районирования территории Кыргызской Республики (Объяснительная записка). Бишкек, Илим, 2012, 51 с.

Абдрахматов К.Е., Уэлдон Р., Томпсон С., Бурбанк Д., Рубин Ч., Миллер М., Молнар П. Происхождение, направление и скорость современного сжатия Центрального Тянь-Шаня (Киргизия) // Геология и геофизика, 2001, т. 42, № 10, с. 1585-1609.

Айталиев Ш.М. (ред.) Жаланаш-Тюпское землетрясение 25 марта 1978 г. Алма-Ата, Наука, 1981, 136 с.

Алешинская 3.В., Бондарев Л.Г., Воскресенская Т.Н., Лефлат О.Н. Разрез новейших отложений Иссык-Кульской впадины. Москва, МГУ, 1971, 164 с.

Бачманов Д.М., Кожурин А.И., Трифонов В.Г. База данных активных разломов Евразии // Геодинамика и тектонофизика, 2017, т. 8, № 4, с. 711-736.

Богданович К.И., Карк И.М., Корольков Б.Я., Мушкетов Д.И. Землетрясение в северных цепях Тянь-Шаня 22 декабря 1911 г. (4 января 1911 г.). Труды Геол. комитета. Новая серия. СПб., 1914, вып. 89, 256 с.

Григоренко П.Г., Мамыров Э., Садыбакасов И., Талипов М.А., Турдукулов А. Геолого-структурные и инженерно-геологические условия района Сыры-Камышского землетрясения. Фрунзе, Илим, 1973, 100 с.

Деев Е.В. Неотектоника и палеосейсмичность внутригорных впадин северной части Центральной Азии (на примере Горного Алтая и Северного Тянь-Шаня): Автореф. дис. ... д.г.-м.н. Новосибирск, ИНГГ СО РАН, 2018, 50 с.

Деев Е.В., Корженков А.M. Палеосейсмологические исследования в эпицентральной зоне Кеминского землетрясения 1911 г. в Северном Тянь-Шане // Геология и геофизика, 2016, т. 57, № 2, с. 421-430.

Деев Е.В., Турова И.В., Корженков А.М., Лужанский Д.В., Гладков А.С., Родкин М.В., Абдиева С.В., Мажейка И.В., Рогожин Е.А., Фортуна А.Б., Муралиев A.M., Чаримов T.A., Юдахин А.С. Результаты палеосейсмологических и археосейсмологических исследований в западной части АлабашКонуроленскойвнутригорной впадины (Южное Прииссыккулье, Кыргызстан) // Геология и геофизика, 2016, т. 57, № 7, с. 1381-1392.

Джанузаков К., Омуралиев М., Омуралиева А., Ильясов Б., Гребенникова В.В. Сильные землетрясения Тянь-Шаня (в пределах территории Кыргызстана и прилегающих районов стран Центральной Азии). Бишкек, Илим, 2003, 216 с. 
Кальметьева 3.А., Миколайчук А.В., Молдобеков Б.Д., Мелешко А.В., Жантаев М.М., Зубович А.В. Атлас Землетрясений Кыргызстана. Бишкек, ЦАИИЗ, 2009, 73 с.

Корженков А.М. Особенности строения и формирования морфоструктур на югозападе Иссык-Кульской впадины // Известия АН Кирг. ССР, 1987, № 2, с. 54-59.

Корженков А.М. Тектоника кайнозоя и сейсмичность северо-западной части ИссыкКульской впадины (Тянь-Шань) // Геология и геофизика, 2000, т. 41, № 7, с. 971-982.

Корженков А.М. Сейсмогеология Тянь-Шаня (в пределах территории Кыргызстана и прилегающих районов). Бишкек, Изд-во Илим, 2006, 289 с.

Корженков А.М., Поволоцкая И.Э., Мамыров Э. Морфологическое выражение четвертичной деформации в северо-западных предгорьях Иссыккульской впадины ТяньШаня // Геотектоника, 2007, № 2, с. 53-72.

Корженков А.М., Абдиева С.В., Вахрамеева П.С., Джумабаева А.Б., Мамыров Э., Морозова Е.А., Орлова Л.А., Фортуна А.Б. Сильные исторические землетрясения на северо-западе Иссык-Кульской впадины (Северный Тянь-Шань) // Геология и геофизика, 2011, т. 52, № 9, 2011, с. 1276-1286.

Корженков А.М., Рогожин Е.А., Шен Ю., Деев Е.В., Абдиева С.В., Фортуна А.Б., Муралиев А.М., Чаримов Т.А., Юдахин А.С., Мажейка Й. Палеосейсмологические и археосейсмологические исследования по международным проектам РФФИ // Вестник РФФИ, 2014, № 1 (81), с. 15-20.

Корженков А.М., Кольченко В.А., Лужанский Д.В., Рогожин Е.А., Казмер М., Мажейка Й.В., Деев Е.В., Фортуна А.Б., Шен Д., Юдахин А.С., Абдиева С.В., Родина С.Н. Археосейсмологическое исследование Курментинского средневекового городища (Северо-Восточное Прииссыккулье, Кыргызстан) // Вопросы инженерной сейсмологии, 2015, т. 42, № 1, с. 70-81.

Корженков А.М., Абдиева С.В., Агатова А.P., Арроусмит Р., Бауман Д., Вахрамеева П.С., Гладков А.С., Гуральник Б., Деев Е.В., Джумабаева А.Б., Казмер М., Керимбаева Д., Кольченко В., Кросби К., Лобова (Казанцева) Е.Ю., Лужанский Д.В., Мажейка Й.В., Мамыров Э., Меньшиков М.Ю., Морозова Е.А., Муралиев А.М., Нурманбетов К., Орлова Л.А., Павлис Т.Л., Поволоцкая И.Э., Порат Н., Рогожин Е.А., Родина С.Н., Родкин М.В., Сорокин А.А., Табалдиев К., Турова И.В., Усманов С.Ф., Фортуна А.Б., Чаримов Т.А., Шен Д., Юдахин А.С. Сильные исторические и палеоземлетрясения Прииссыккулья и их положение в структуре Северного Тянь-Шаня. М., ИФЗ РАН, 2018а, 174 с.

Корженков А.М., Абдиева С.В., Гладков А.С., Деев Е.В., Лю Ц., Мажейка Й.В., Рогожин Е.А., Родкин М.В., Сорокин А.А., Турова И.В., Фортуна А.Б. 
Палеосеймичность вдоль адырных разломов (на примере Коконадыр-Тегерекского разлома в Юго-Западном Приссыккулье, Тянь-Шань) // Вулканология и сейсмология, 2019, № 5.

Корженков А.М., Деев Е.В., Лужанский Д.В., Абдиева С.В., Агатова А.Р., Мажейка Й.В., Менышиков М., Рогожин Е.А., Родина С.Н., Родкин М.В., Сорокин А.А., Фортуна А.Б., Чаримов Т.А., Шен Д., Юдахин А.С. Сильное средневековое землетрясение в Северном Прииссыккулье (Тянь-Шань): результаты палеосейсмологических и археосейсмологических исследований // Геофизические процессы и биосфера, 2016а, т. 15, № 4, с. 43-63.

Корженков А.М., Кольченко В.А., Лужанский Д.В., Абдиева С.В., Деев Е.В., Мажейка Й.В., Рогожин Е.А., Родина С.Н., Родкин М.В., Фортуна А.Б., Чаримов Т.А., Юдахин А.С. Археосейсмологические исследования и структурная позиция средневековых землетрясений на юге Иссык-Кульской впадины (Тянь-Шань) // Физика Земли, 2016б, № 2, с. 71-86.

Корженков А.М., Лужанский Д.В., Абдиева С.В., Деев Е.В., Павлис Т.Л., Рогожин Е.А., Турова И.В., Юдахин А.С. О следах сильного землетрясения в стенах средневековых городищ Сары-Булун на Великом шелковом пути (Западное Прииссыккулье, Северный Тянь-Шань) // Вопросы инженерной сейсмологии, 2016в, т. 43, № 4, с. 5-20.

Корженков А.М., Эрроусмит Р., Кросби К., Гуральник Б., Рогожин Е.А., Сорокин А.А., Абдиева С.В., Фортуна А.Б., Юдахин А.С., Агатова А.Р., Деев Е.В., Мажейка Й.В., Родкин М.В., Шен Д. Сильные палеоземлетрясения вдоль Аксуйского краевого разлома по материалам датирования разорванного террасового комплекса реки Чон-Аксуу, Северный Тянь-Шань // Физика Земли, 2018б, № 2, с. 64-80.

Поволоцкая И.Э., Корженков А.М., Мамыров Э.М. Следы сильных землетрясений в озерных осадках Кок-Мойнокской впадины (Северный Тянь-Шань) // Геология и геофизика, 2006, т. 47, № 9, с. 1024-1035.

Турчинский В.П. Геологическая карта СССР. М-б 1:200 000. Серия Северо-ТяньШаньская. K-43-XVIII. Л., Картфабрика ВАГТ, 1970. 1 лист.

Утиров Ч.У. Сейсмодислокации // Геологические основы сейсмического районирования Иссык-Кульской впадины. Фрунзе, Илим, 1978, с. 91-111.

Утиров Ч.У. Сейсмодислокации и палеосейсмодислокации // Детальное сейсмическое районирование Иссык-Кульской впадины. Бишкек, Илим, 1993, с. 113-125.

Фортуна А.Б. Мезозойские и палеоген-неогеновые отложения // Детальное сейсмическое районирование Иссык-Кульской впадины. Бишкек, Илим, 1993, с. 11-15. 
Чабдаров Н.М., Стариченко Ф.А., Бажанова О.В. Геологическая карта СССР. М-б 1:200 000. Серия Северо-Тянь-Шаньская. K-44-VII. Л., Картфабрика Госгеолтехиздата Министерства геологии и охраны недр, 1961. 1 лист.

Чедия О.K. Морфоструктуры и новейший тектогенез Тянь-Шаня. Фрунзе, Илим, 1986, 316 с.

Чедия О.К., Джумадылова Ч.К., Трунилин С.И. Предтерскейский краевой разлом в междуречье Джетыогуз-Тоссор // Известия АН Кирг. ССР, 1988, № 1, с. 79-88.

Шендерович Д.М., Макаров В.А. Геологическая карта СССР. М-б 1:200 000. Серия Северо-Тянь-Шаньская. К-44-ХІІІ. Л., Картфабрика ВАГТ, 1965. 1 лист.

Bezerra F.H.R., Fonseca V.P., Vita-Finzi C., Lima-Filho F.P., Saadi A. Liquefactioninduced structures in Quaternary alluvial gravels and gravels sediments, NE Brazil // Engineering Geology, 2005, v. 76, p. 191-208.

Bowman D., Korjenkov A.M., Porat N. Late-Pleistocene seismites from Lake Issyk-kul, the Tien Shan range, Kyrghyzstan // Sedimentary Geology, 2004a, v. 163, p. 211-228.

Bowman D., Korjenkov A., Porat N., Czassny B. Morphological response through competing of thrusting and erosion, at basin foothills, the northern Tien Shan, Kyrghyzstan // Geomorphology, 2004b, v. 63, p. 1-24.

Bronk Ramsey C. Development of the radiocarbon calibration program OxCal // Radiocarbon, 2001, v. 43, p. 355-363.

Bronk Ramsey C., Dee M., Lee S., Nakagawa T., Staff R. Developments in the calibration and modelling of radiocarbon dates // Radiocarbon, 2010, v. 52, p. 953-961.

Burgette R.J. Uplift in response to tectonic convergence: The Kyrgyz Tien Shan and Cascadia subduction zone [Ph.D. thesis]. USA, University of Oregon, 2008, 242 p.

Chediya O.K., Abdrakhmatov K.E., Lemzin I. N., Mihel G., Mikhaylev V. Issyk-Ata, Northern Tien Shan fault in the Holocene // Journal of Earthquake Prediction Research, 2000, v. 8, p. 379-386.

Deev E., Turova I., Borodovskiy A., Zolnikov I., Pozdnyakova N., Molodkov A. Large earthquakes in the Katun Fault zone (Gorny Altai): Paleoseismological and archaeoseismological evidence // Quaternary Science Reviews, 2019, v. 203, p. 68-89.

Deev E., Korzhenkov A., Turova I., Pavlis T.L., Luzhanskii D., Mažeika J., Abdieva S., Yudakhin A. Large ancient earthquakes in the western Issyk-Kul basin (Kyrgyzstan, northern Tien Shan) // Journal of Asian Earth Sciences, 2018, v. 166, p. 48-65.

Gladkov A.S., Lobova E.U., Deev E.V., Korzhenkov A., Mazeika J.V., Abdieva S.V., Rogozhin E.A., Rodkin M.V., Fortuna A.B., Charimov T.A, Yudahin A.S. Earthquake- 
induced soft-sediment deformation structures in Late Pleistocene lacustrine deposits of Issyk-Kul lake (Kyrgyzstan) // Sedimentary Geology, 2016, v. 344, p. 112-122.

Korjenkov A.M. Seismogenic convolutions in soft lacustrine sediments of the Issyk Kul Lake, Tien Shan, Kirgizstan - Initial report // Journal of Earthquake Prediction Research, 2000, v. 8, № 4, p. 514-519.

Korjenkov A.M., Arrowsmith J.R., Crosby C., Mamyrov E., Orlova L.A., Povolotskaya I.E., Tabaldiev K. Seismogenic destruction of the Kamenka medieval fortress, northern Issyk-Kul region, Tien Shan (Kyrgyzstan) // Journal of Seismology, 2006a, no. 10, p. 431-442.

Korjenkov A., Bowman D., Haselton K., Porat N. Recent drainage diversions under thrusting conditions in the Suusamyr Valley, the Tien Shan Range, Kyrgyzstan // Isr. J. Earth Sci., 1999, v. 48, p. 63-79.

Korjenkov A.M., Michajljow W., Wetzel H.-U., Abdybashev U., Povolotskaya I.E. Field excursion guidebook. International training course «Seismology and Seismic Hazard Assessment». Bischkek-Potsdam, GFZ-ZAIAG, 2006b, 112 p.

Korzhenkov A.M., Deev E.V. Underestimated seismic hazard in the south of the IssykKul Lake region (Northern Tien Shan) // Geodesy and Geodynamics, 2017, v. 8, is. 3, p. 169180.

Macaulay E.A., Sobel E.R., Mikolaichuk A., Kohn B., Stuart F.M. Cenozoic deformation and exhumation history of the Central Kyrgyz Tien Shan // Tectonics, 2014, v. 33, is. 2, p. $135-165$.

Mackenzie D., Walker R., Abdrakhmatov K., Campbell G., Carr A., Gruetzner C., Mukambayev A., Rizza M. A creeping intracontinental thrust fault: past and present slip-rates on the northern edge of the Tien Shan, Kazakhstan // Geophysical Journal International, 2018, v. 215, is. 2, p. 1148-1170.

Nikonov A.A. Reconstruction of the main parameters of old large earthquakes in Soviet Central Asia using the paleoseismogeological method // Tectonophysics, 1988, v. 147, p. 297312.

Papathanassiou G., Pavlides S., Christaras B., Pitilakis K. Liquefaction case histories and empirical relations of earthquake magnitude versus distance from the boarder Aegean region // J. Geodynam., 2005, v. 40, p. 257-278.

Reimer P.J., Bard E., Bayliss A., Beck J.W., Blackwell P.G., Ramsey C.B., Buck C.E., Cheng H., Edwards R.L., Friedrich M., Grootes P.M., Guilderson T.P., Haflidason H., Hajdas I., Hatté C., Heaton T.J., Hoffmann D.L., Hogg A.G., Hughen K.A., Kaiser K.F., Kromer B., Manning S.W., Niu M., Reimer R.W., Richards D.A., Scott E.M., Southon J.R., 
Staff R.A., Turney C.S.M., van der Plicht J. IntCal13 and Marine13 Radiocarbon Age Calibration Curves 0-50,000 Years cal BP // Radiocarbon, 2013, v. 55, № 4, p. 1869-1887.

Rodríguez-Pascua M.A., Calvo J.P., De Vicente G., Gómez-Gras D. Soft-sediment deformation structures interpreted as seismites in lacustrine sediments of the Prebetic Zone, SE Spain, and their potential use as indicators of earthquake magnitudes during the Late Miocene // Sedimentary Geology, 2000, v. 135, p. 117-135.

Selander J., Oskin M., Ormukov Ch., Abdrakhmatov K. Inherited strike-slip faults as an origin for basement-cored uplifts: Example of the Kungey and Zailiskey ranges, northern Tian Shan // Tectonics, 2012, v. 31, p. TC4026.

Thompson S.C. Active Tectonics in the Central Tien Shan, Kyrgyz Republic [Ph.D. thesis]. Seattle, University of Washington, 2001, 141 p.

Wells D.L., Coppersmith K.J. New empirical relationship among magnitude, rupture length, rupture width, rupture area and surface displacement // Bull. Seismol. Soc. Am., 1994, v. 84, № 4, p. 974-1002. 
Подрисуночные подписи к статье А.М. Корженкова, Е.В.Деева, И.В.Туровой и др.

\section{АКТИВНАЯ ТЕКТОНИКА И ПАЛЕОСЕЙСМИЧНОСТЬ ВОСТОЧНОЙ ЧАСТИ ИССЫК-КУЛЬСКОЙ КОТЛОВИНЫ (КЫРГЫЗСТАН, ТЯНЬ-ШАНЬ)}

Рис. 1. Основные активные структуры Прииссыккулья. Внутривпадинные поднятия (цифры в белых кругах): 1 - Боз-Бармак, 2 - Малый Оргочор, 3 - Оргочор, 4 - Бирбаш, 5 Сухой Хребет, 6 - Ичкетосма, 7 - Тосма. Эпицентры исторических и инструментально зарегистрированных землетрясений за период с 250 г. до н.э. по 2014 г. приведены по данным (Кальметьева и др., 2009), сейсмологических каталогов NEIC и IRIS. A-Б - линия схематического разреза, представленного на рис. 12 б. Оттененный рельеф создан с использование пакета GeoMapApp (http://www.geomapapp.org).

Рис. 2. а: сегменты Южно-Иссыккульского активного разлома, осложняющие северные крылья Малой Оргочорской и Оргочорской антиклиналей. В качестве основы использован космоснимок QuickBird (http://earth.google.com). б, в: положение ЮжноИссык-Кульского разлома на северном крыле Малой Оргочерской антиклинали. Здесь и далее фотографии А.М.Корженкова.

Рис. 3. Деформации неоген-четвертичных отложений на западной периклинали Оргочерской антиклинали, в зоне Южно-Иссыккульского разлома. а: Моноклинальное залегание неогеновых отложений иссык-кульской свиты на крутом и коротком северном крыле Оргочорской антиклинали в естественном обнажении к востоку от дороги ОргочорБозбешик. Пунктирные линии подчеркивают положение поверхностей напластования. б: Два сейсмоуступа в месте пересечения Оргочорского поднятия р. Чон-Кызылсуу. Стрелками показаны бровки уступов, пунктирными линиями - их основания. в: Югозападная стенка придорожного карьера на северной окраине с. Боз-Бешик. Сейсмогенные конволюции (сейсмиты) в толще переслаивающихся верхнеплейстоценовых озерных глин и аллювиальных галечников.

Рис. 4. Сегменты Южно-Иссыккульского активного разлома в районе внутривпадинного поднятия Бирбаш. В качестве основы использован космоснимок QuickBird (http://earth.google.com). 
Рис. 5. Активная тектоника на северном склоне горы Бирбаш. а: разломные уступы на северном склоне г. Бирбаш. В качестве основы использована фотосъемка с квадрокоптера. б: нижний разломный уступ. Человек в овале для масштаба. в: сегменты двух сближенных разломных уступов. Высота уступов 1.5-2.5 м. Стрелками показаны бровки уступов, пунктирными линиями - их основания.

Рис. 6. Исследование структуры разломных уступов на северном склоне горы Бирбаш. а: Фотография уступа в месте заложения траншеи (пунктирная линия). Люди стоят на его бровке и подножье. б: Разрез восточной стенки траншеи. Цифрами обозначены номера слоев. Описание слоев см. в тексте. в: Левосдвиговое смещение русла временного водотока вдоль разломного уступа.

Рис. 7. Сейсмиты в отложениях николаевской озерной террасы (Q обнажения. б: Складки и конволютная слоистость. в: пламеневидные структуры и структуры нагрузки.

Рис. 8. Разломный уступ к западу от антиклинали Бирбаш. а: Общий вид уступа. Вид на запад. Стрелками показана бровка уступа, пунктирной линией - его основание. б и в вторичные сейсмогенные деформации в верхнеплейстоценовых отложениях, вскрытых в карьере в восточной части уступа: малоамплитудный взбросо-надвиг (б), малоамплитудный надвиг и отторженцы озерных глин, погрузившиеся в галечники в процессе сейсмического разжижения (в). Пунктирными линиями показаны смещенные маркирующие поверхности.

Рис. 9. Активная тектоника на северном склоне Сухого Хребта. а: Сегменты Каркаринского разлома. В качестве основы использован космоснимок QuickBird (http://earth.google.com). б: один из разломных уступов, образованный в результате подвижек по Каркаринскому разлому. в: субвертикальное падение средневерхнеплейстоценовых озерных глин, скрытых карьером к востоку от пос. Песчаный. Пунктирные линии подчеркивают положение поверхностей напластования. г: Асимметричная антиклиналь второго порядка, осложняющая структуру антиклинали Сухой хребет. Стрелкой показано положение сегмента Каркаринского разлома д: Левостороннее смещение русла временного водотока относительно апекса его пролювиального конуса выноса. Стрелками показано положение активного разлома. В овале показан человек для масштаба. 
Рис. 10. Элементы активной тектоники на северном крыле внутривпадинного поднятия Тосма. а: Положение Каркаринского разлома. В качестве основы использован космоснимок QuickBird (http://earth.google.com). б: надвигание неогеновых отложений иссыккульской свиты на средне-верхнеплейстоценовые аллювиальные галечники в придорожном обнажении в зоне Каркаринского разлома. в: отторженцы неогеновых озерных глин, погрузившиеся в средне-верхнеплейстоценовые аллювиальные галечники в процессе сейсмического разжижения. г: серия разломных уступов в зоне Каркаринского разлома и их кинематика. Сплошные белые линии проведены по основанию уступов. Дама стоит на бровке нижнего уступа. д: Каркаринский разлом (показан белыми стрелками) сечет тело молодого оползня и более старого оползневого тела, на котором уже выработаны позднечетвертичные аллювиальные террасы.

Рис. 11. Морфологические и стратиграфические «ножницы» на северной границе адырных поднятий и полого наклонной аллювиально-пролювиальной равнины. а: внемасштабная схема. б: вид от Оргочорского поднятия на юго-запад.

Рис. 12. а: Формирование рамповой впадины (“Долина цветов”) при встречных движениях по разломам, ограничивающим с юга адырное Джеты-Огузское поднятие и с севера хребет Терскей Ала-Тоо (Предтерскейский разлом), по [Чедия и др., 1988] с изменениями и упрощениями. б: Внемасштабная модель, объясняющая формирование новейших структур Восточного Приссыккулья (линия А-Б на рис. 1). Построена с учетом модели [Burgette, 2008].

Таблица 1. Радиоуглеродные датировки. 


\begin{tabular}{|c|c|c|c|c|c|}
\hline No & $\begin{array}{c}\text { Номер } \\
\text { пробы }\end{array}$ & $\begin{array}{c}\text { Лабораторный } \\
\text { индекс пробы }\end{array}$ & Датируемый материал & $\begin{array}{c}{ }^{14} \mathrm{C} \text { возраст, } \\
\text { годы }( \pm 1 \sigma)\end{array}$ & $\begin{array}{c}\text { Калиброванный возраст } \\
\text { (доверительный интервал } \\
1 \sigma)\end{array}$ \\
\hline 1 & BRB-1 & FTMC-25-4 & Палеопочва & $1936 \pm 39$ & $20-90$ гг. н.э. \\
\hline 2 & BRB-2 & FTMC-25-5 & Гумусированная супесь & $845 \pm 38$ & $1160-1245$ гг. н.э. \\
\hline 3 & ВRB-5 & FTMC-25-7 & Гумусированная супесь & $953 \pm 37$ & $1025-1055$ гг. н.э. \\
\hline
\end{tabular}




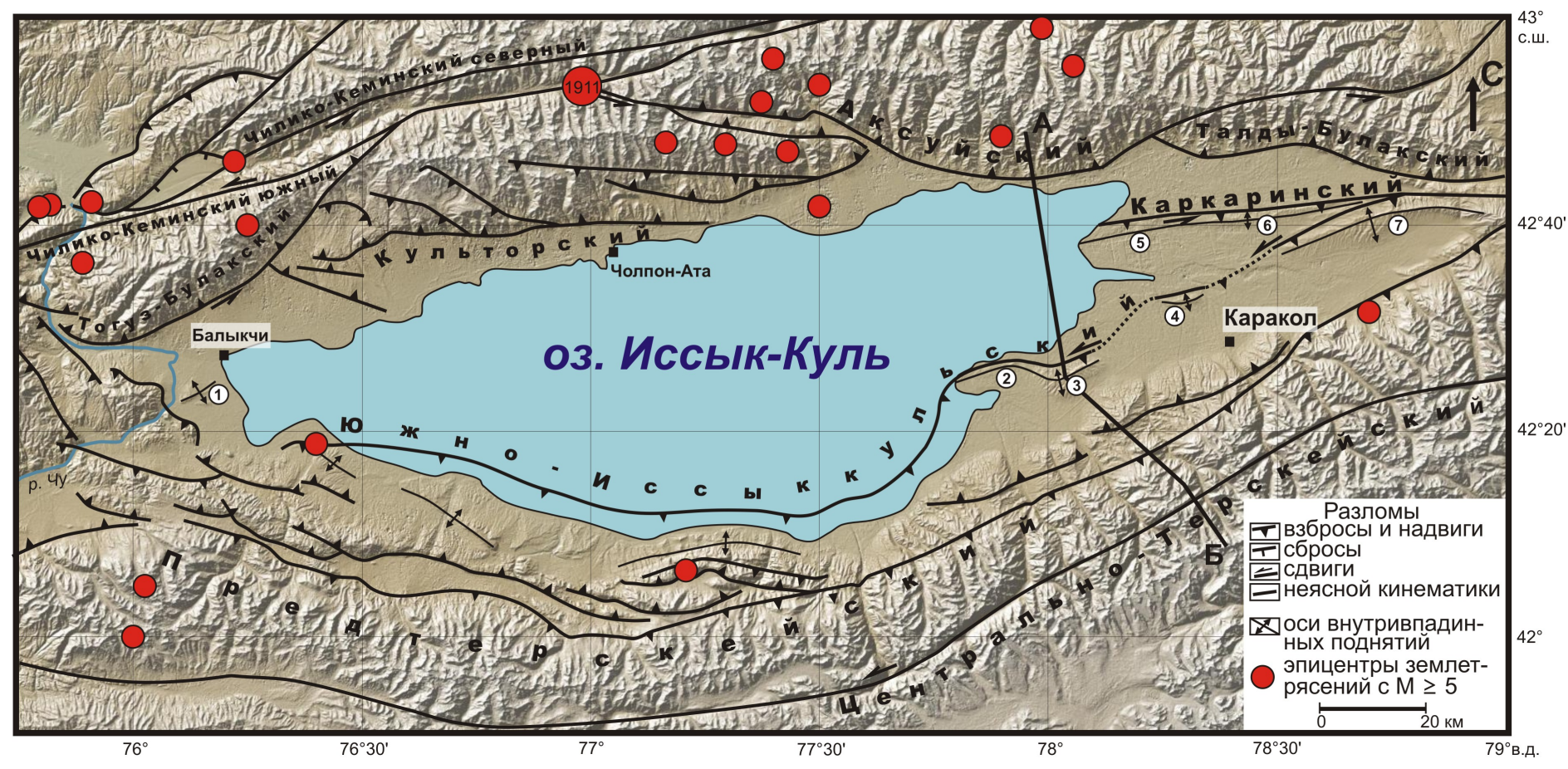




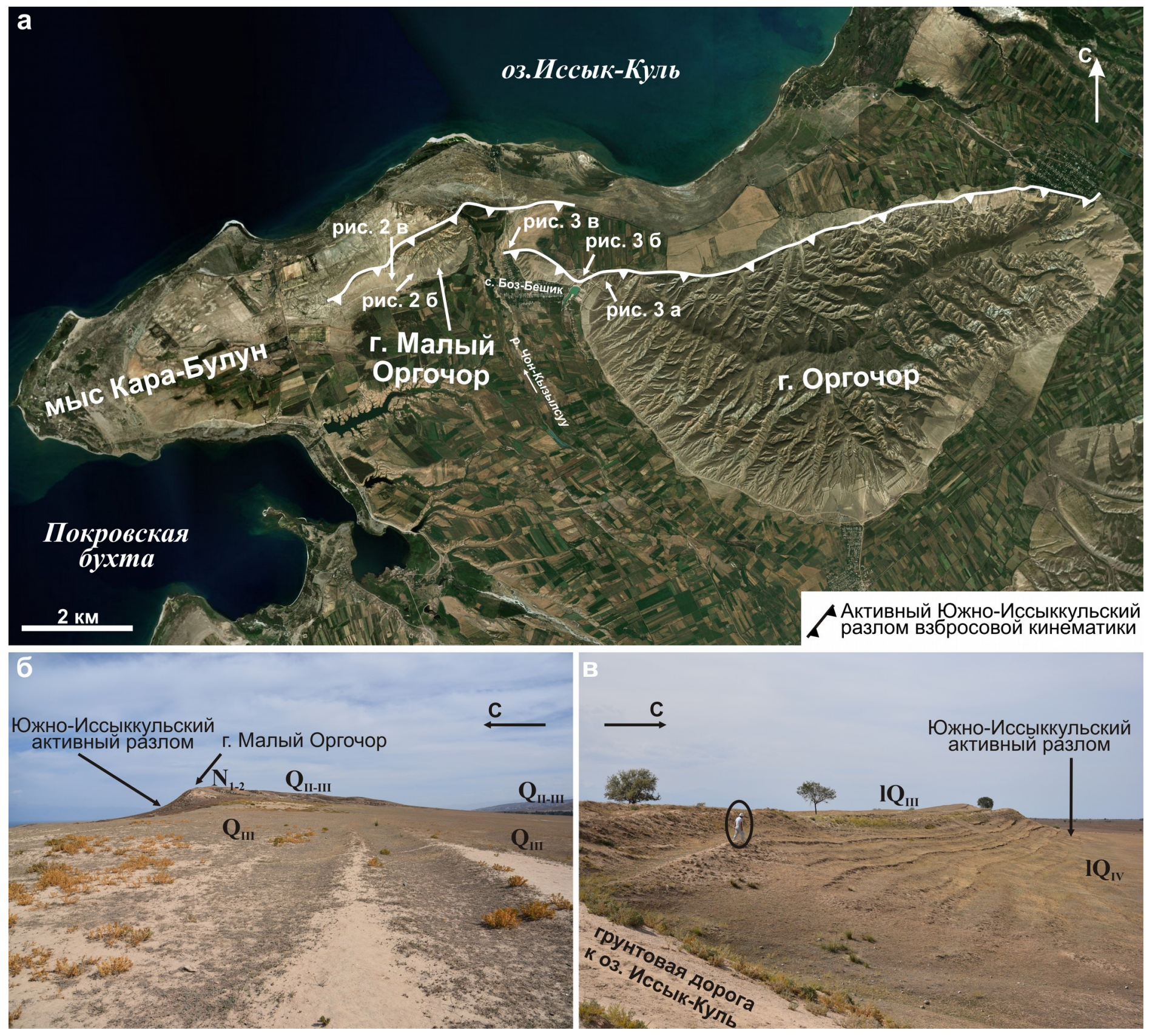




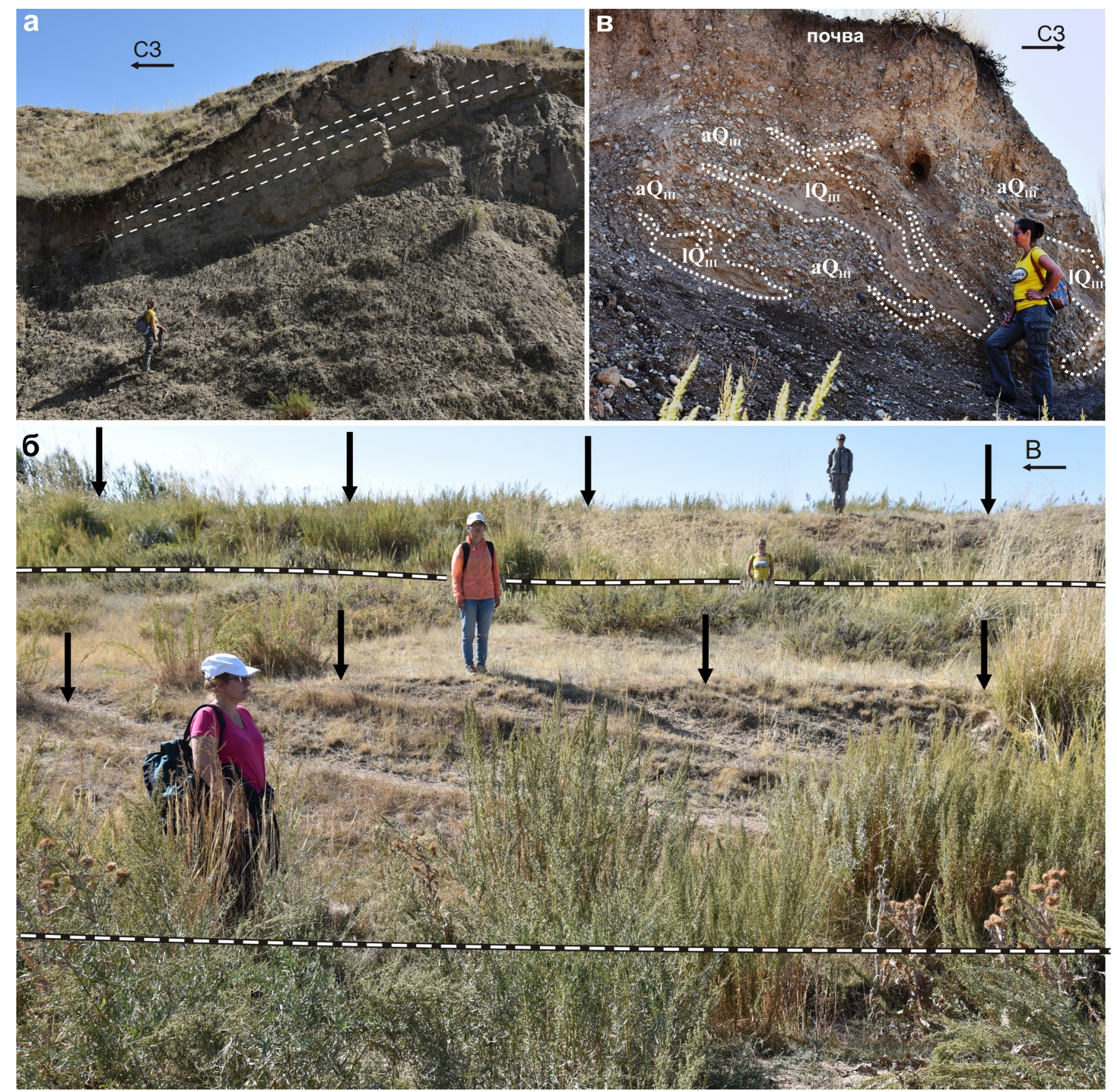




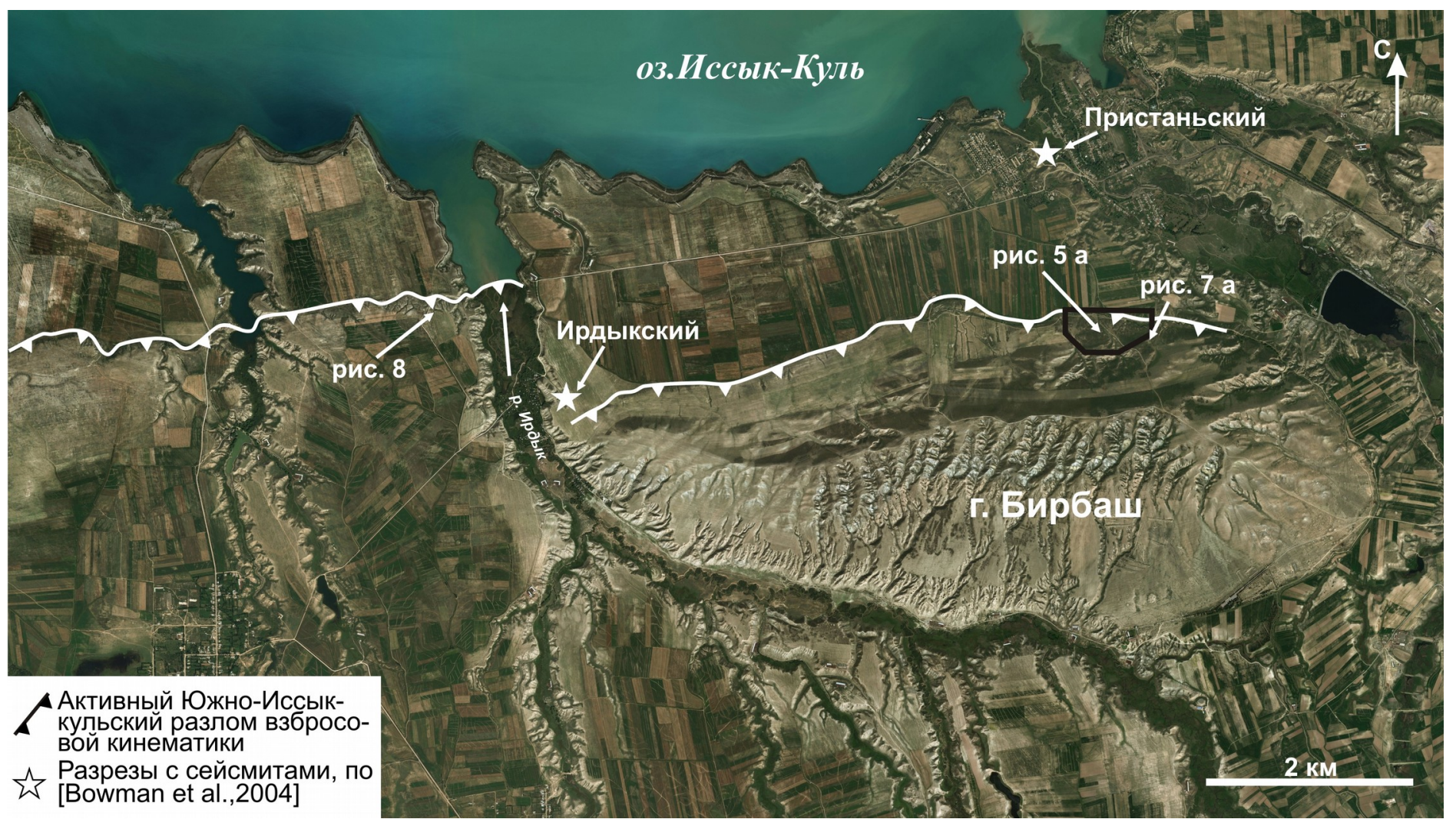




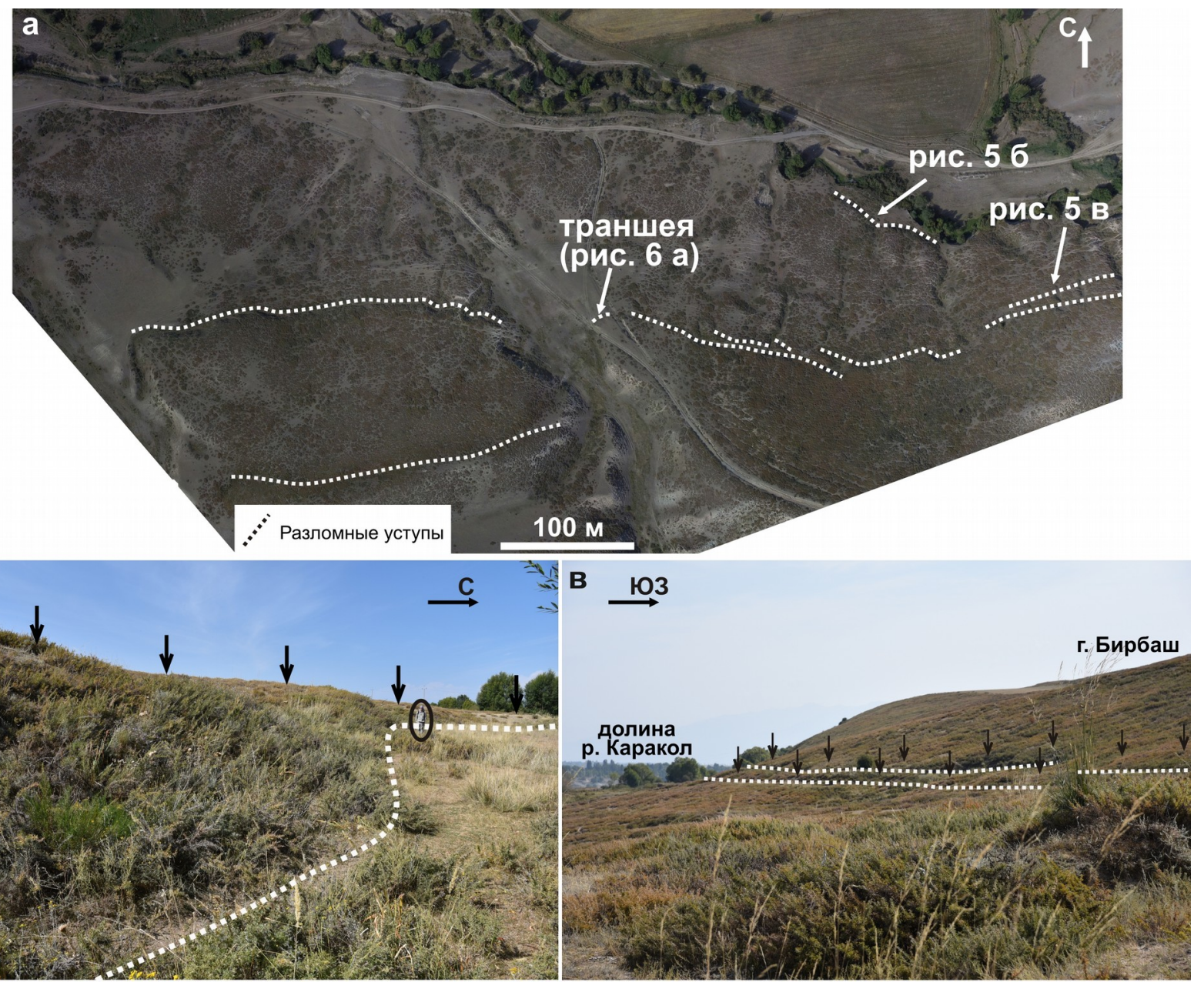




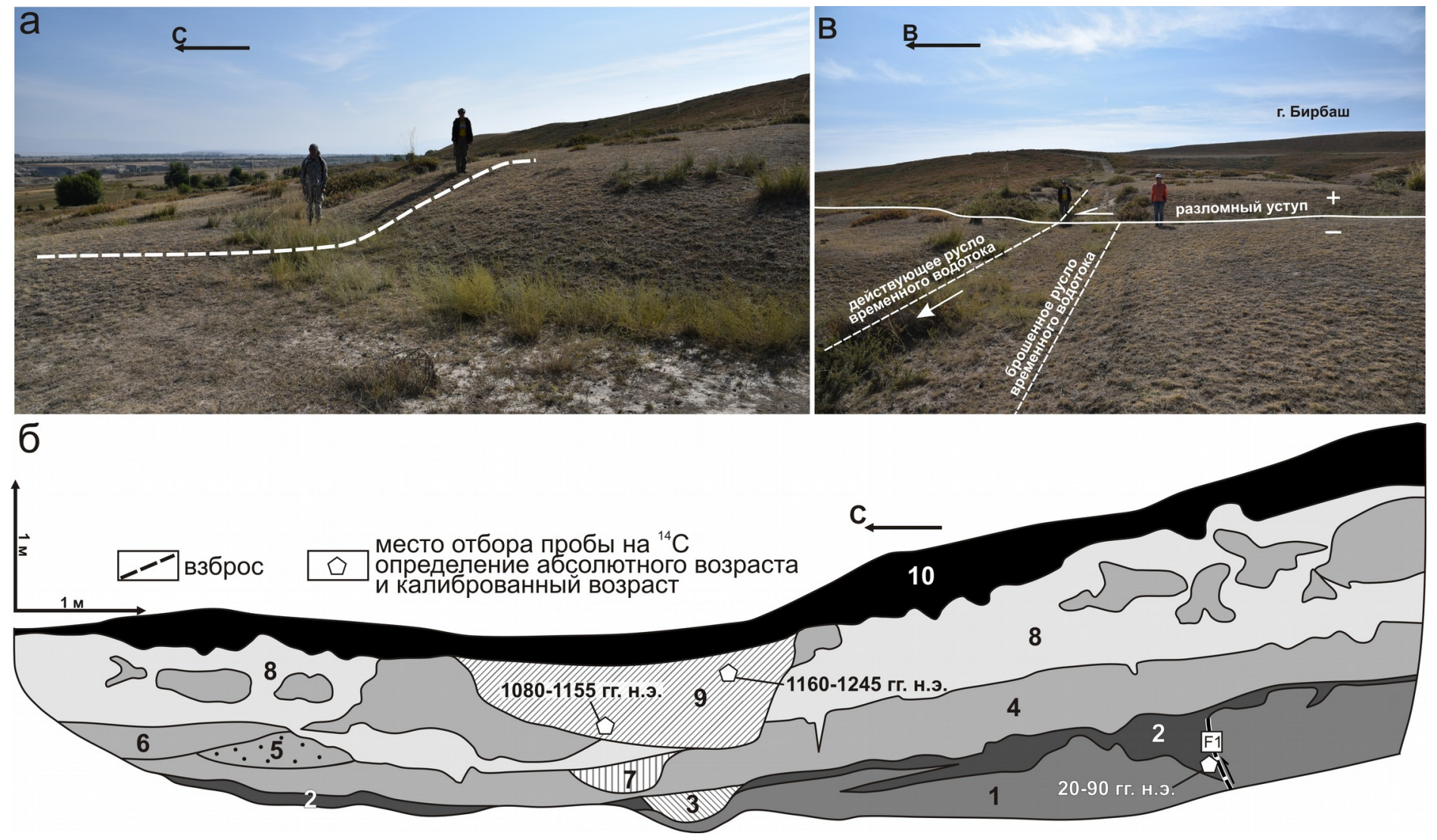




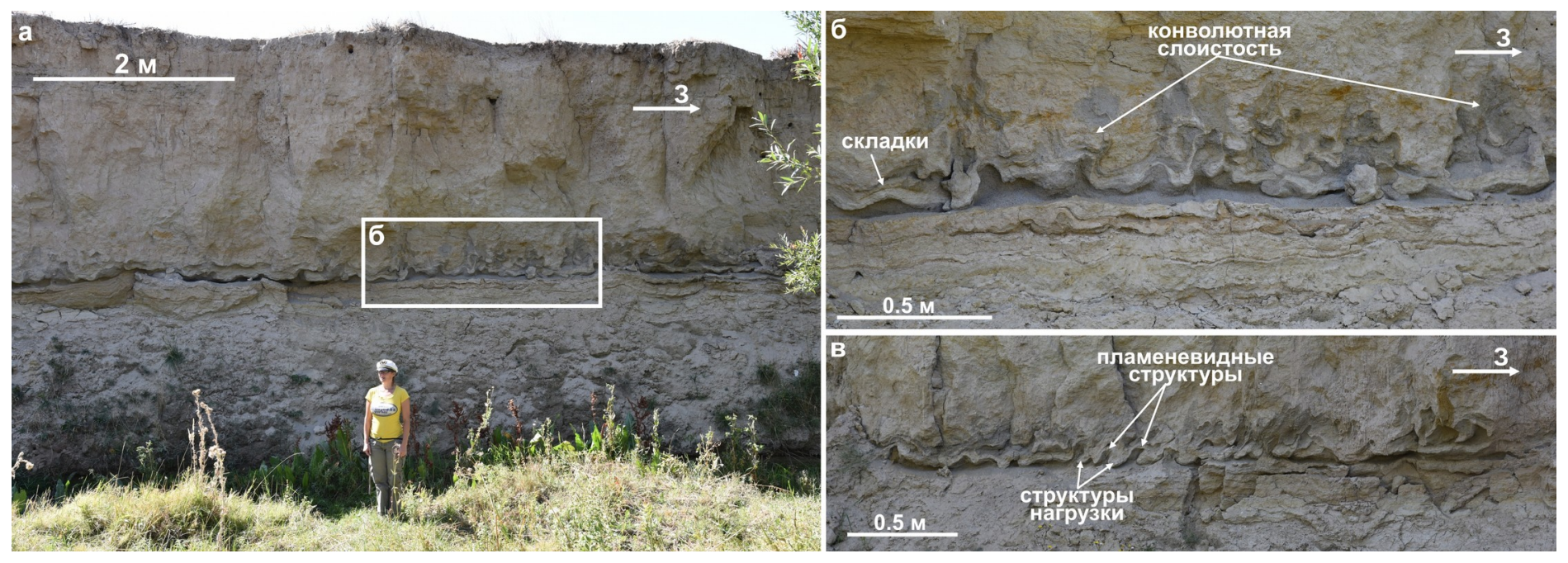




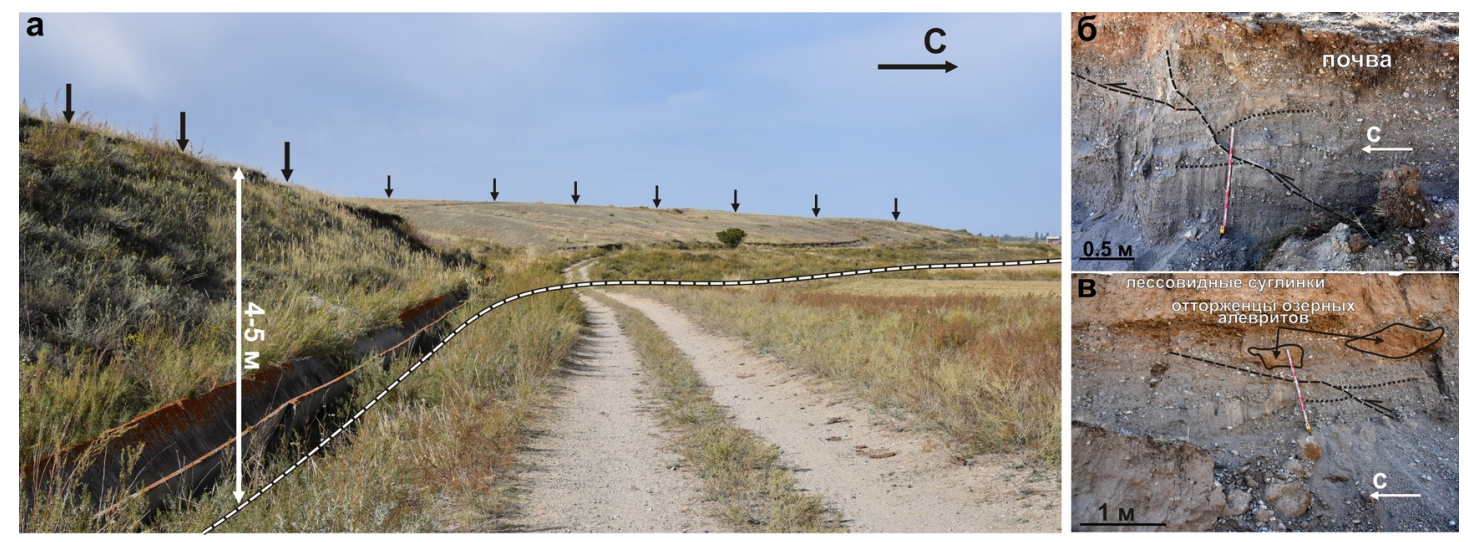




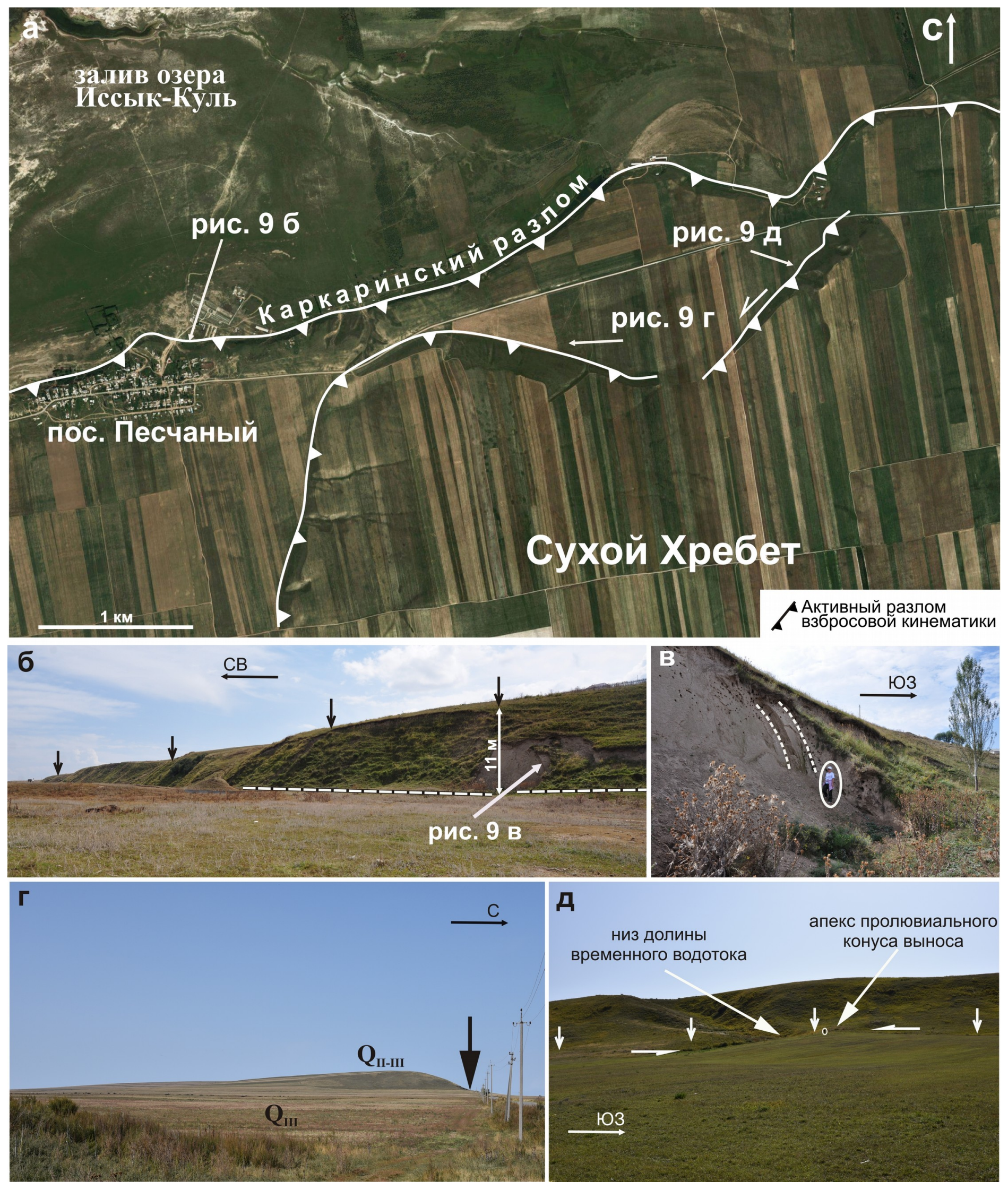



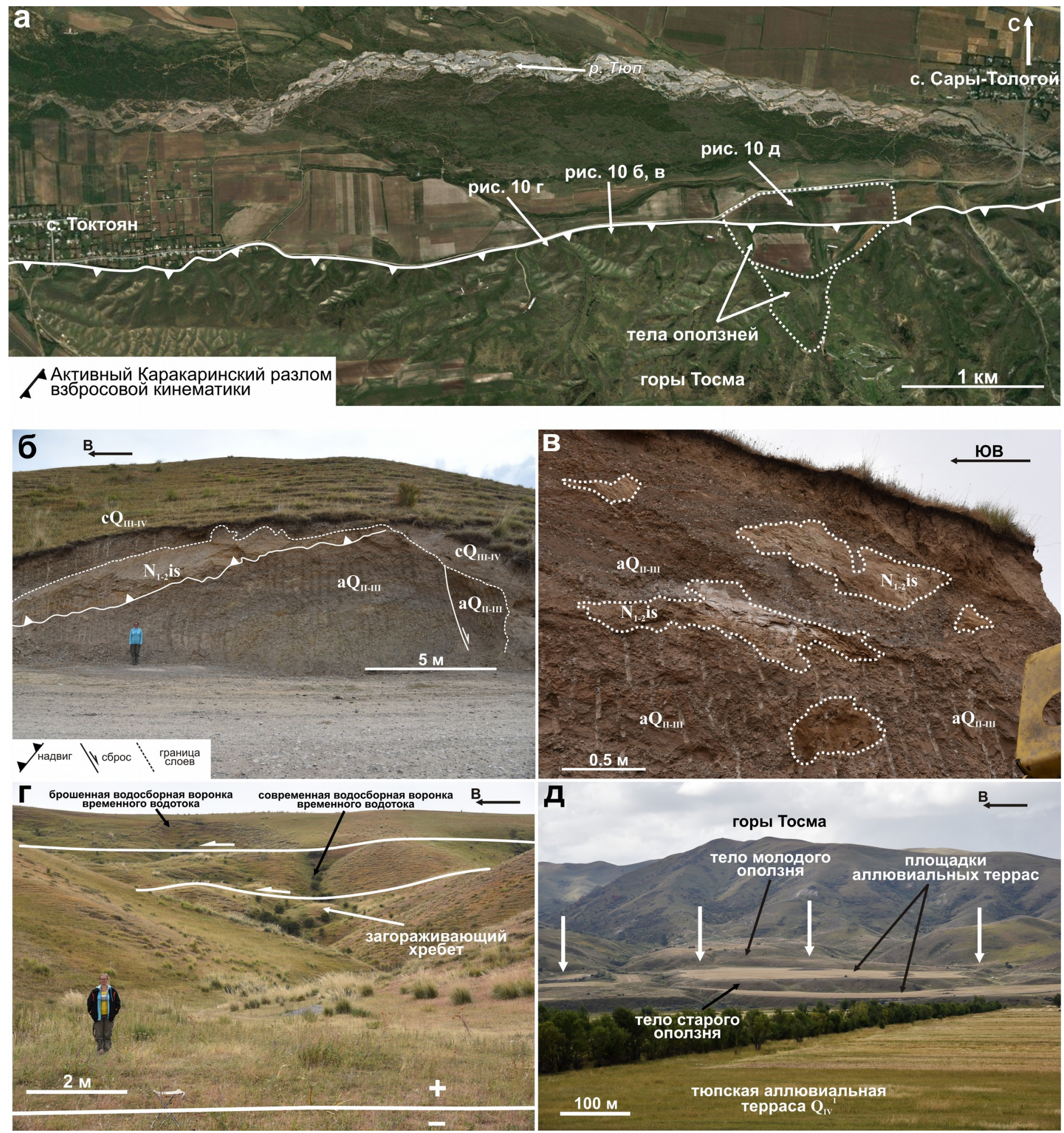


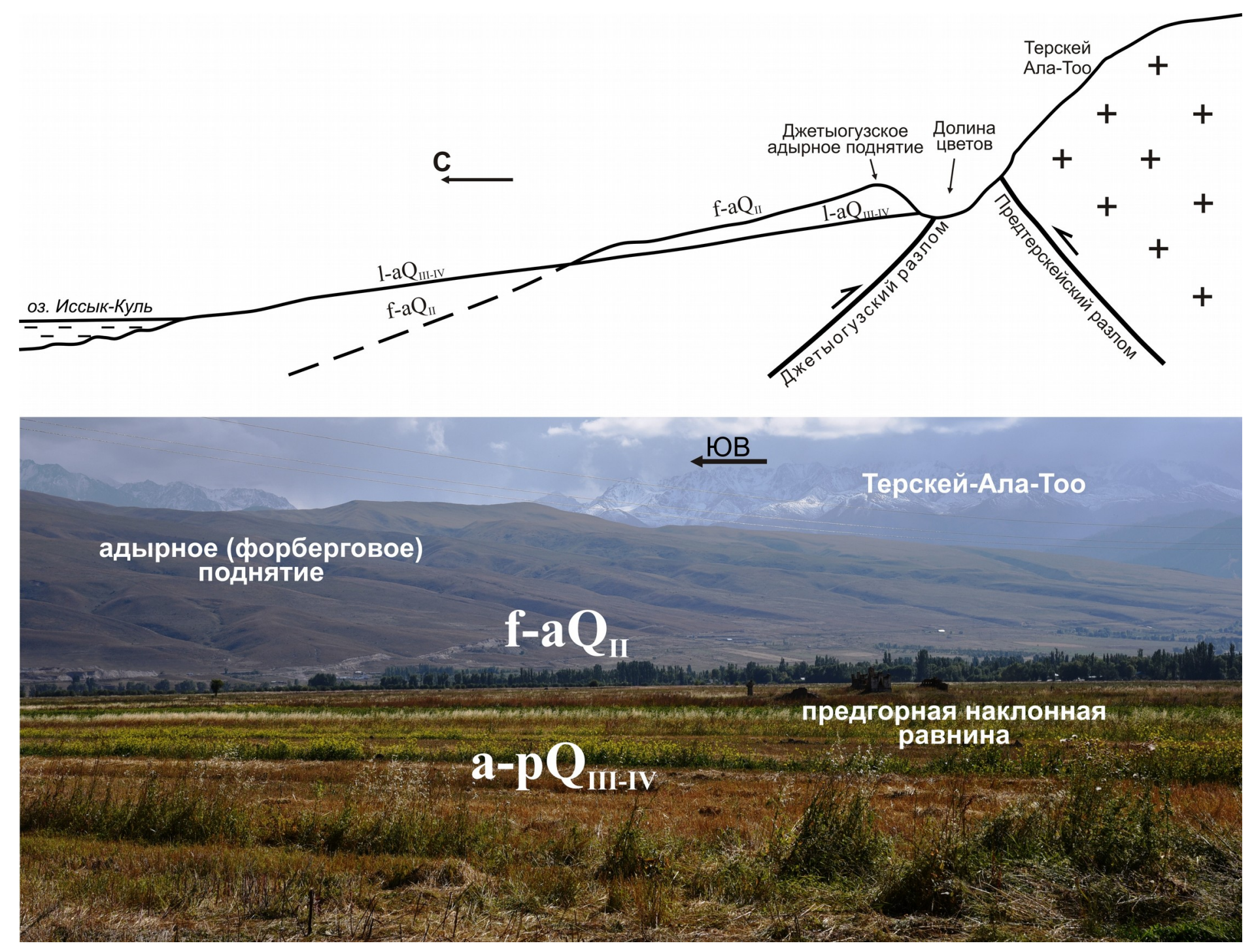


a

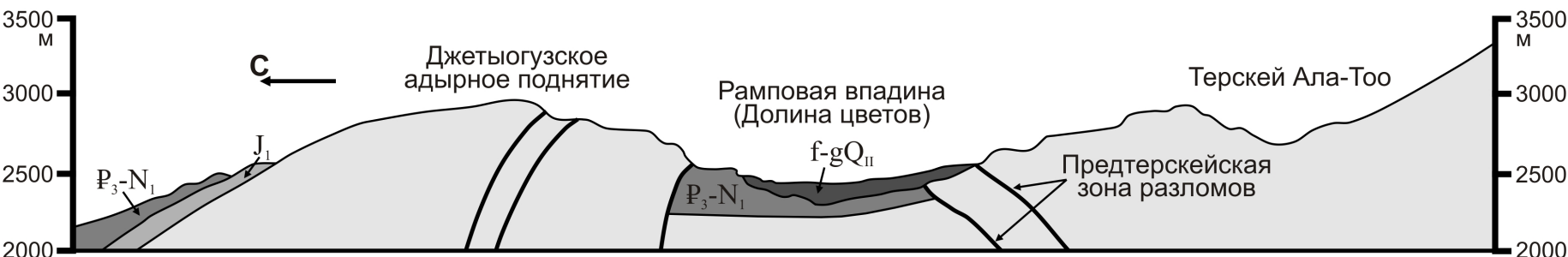

б $\square$ доюрские породы

отложения верхнего палеогена-

нижего неогена

разломы

A

иреднечетвертичные флля

2000

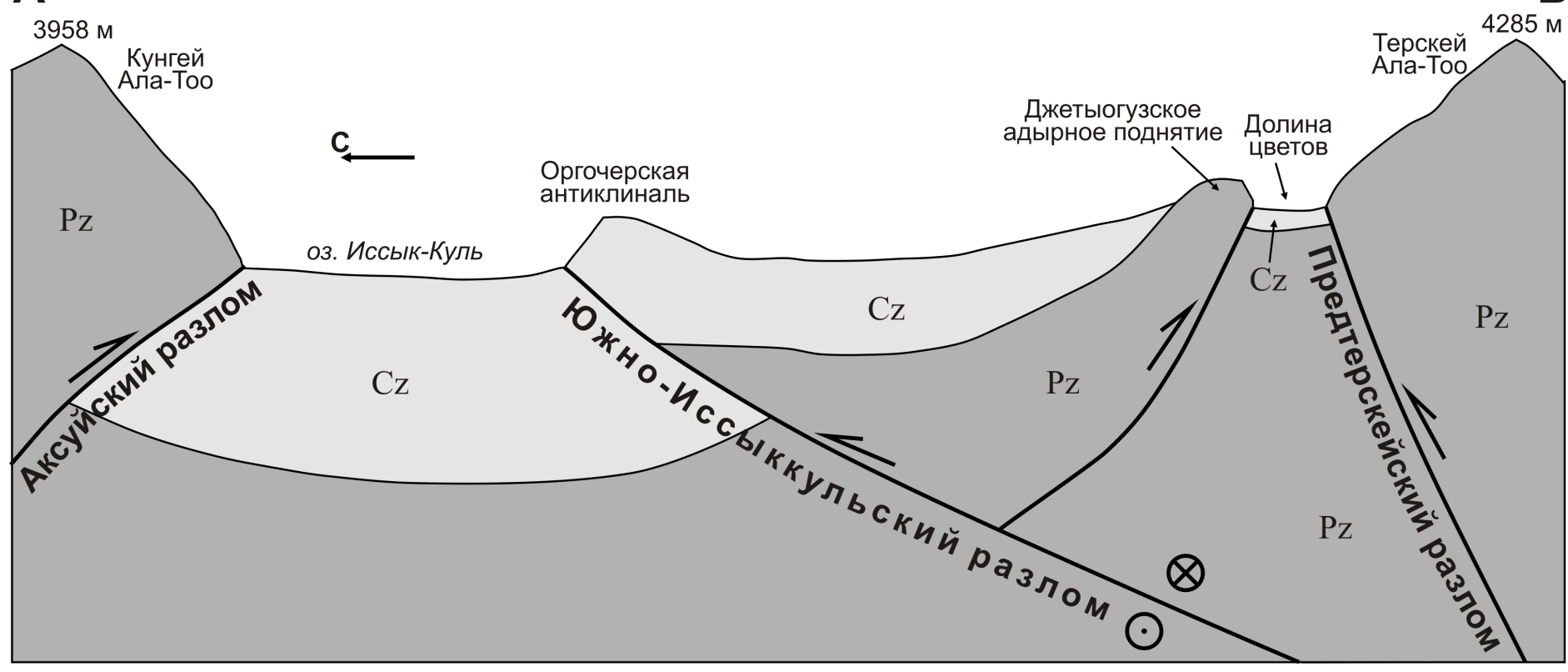

90 кM 